Portland State University

PDXScholar

12-1-1995

\title{
The Leadership of John McLoughlin in Relation to the People and Events of Pacific Northwest History, 1824-1846
}

John David Holliday

Portland State University

Follow this and additional works at: https://pdxscholar.library.pdx.edu/open_access_etds

Part of the History Commons

Let us know how access to this document benefits you.

\section{Recommended Citation}

Holliday, John David, "The Leadership of John McLoughlin in Relation to the People and Events of Pacific Northwest History, 1824-1846" (1995). Dissertations and Theses. Paper 5291.

https://doi.org/10.15760/etd.7164

This Thesis is brought to you for free and open access. It has been accepted for inclusion in Dissertations and Theses by an authorized administrator of PDXScholar. Please contact us if we can make this document more accessible: pdxscholar@pdx.edu. 


\section{THESIS APPROVAL}

The abstract and thesis of J. David Holliday for the Master of Arts in History were presented December 1, 1995, and accepted by the thesis committee and the department.

COMMITTEE APPROVALS:

Gdrdon B. Dodds, Chair

DEPARTMENT APPROVAL:

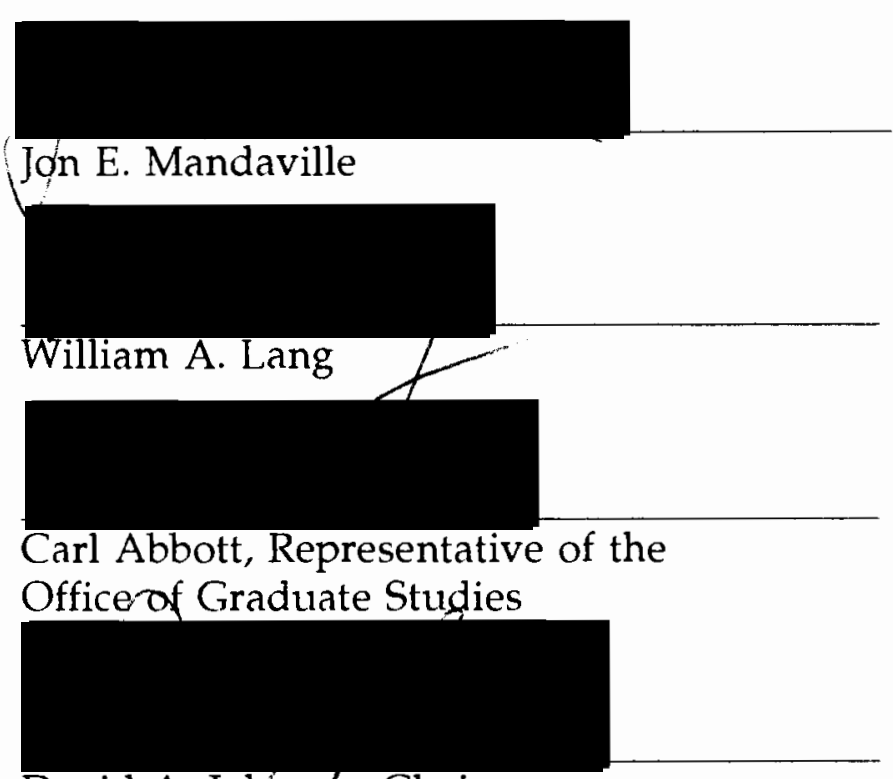

David A. Johrnson, Chair

Department of History

ACCEPTED FOR PORTLAND STATE UNIVERSITY BY THE LIBRARY

by on $\angle-23-46$ 


\begin{abstract}
An abstract of the thesis of J. David Holliday for the Master of Arts in History presented December 1, 1995.
\end{abstract}

Title: The Leadership of John McLoughlin in Relation to the People and Events of Pacific Northwest History, 1824-1846.

In a day when governments, judicial systems, businesses, and religious and social organizations are increasingly faced with such issues as population growth, crime, political correctness, and economic and environmental instability there is a correspondingly increased demand for able, responsible and inspired leaders. Though prominent historical figures took their stand in an era much different from our own, they faced many problems which share a common root with those of any age. A closer look at such individuals not only illuminates the strengths and weaknesses of their characters but offers valuable insights regarding the nature of their failures and successes. It also provides an example or standard from which to measure present and prospective leaders.

The purpose of this study is to take such a look at John McLoughlin, who served as chief factor for the Hudson's Bay Company at Fort Vancouver between the years of 1824-1846. Though much has been written of the man, the intent herein is to examine his leadership qualities in view of the various 
relationships he maintained with the individuals and groups he associated with in the course of his duties. For example, what was his method in dealing with the Native Americans whose way of life was increasingly threatened by the advance of civilization and whose business was important to the success of the fur trade? How did he handle the threat posed by trappers and entrepreneurs who competed openly with the $\mathrm{HBC}$ ? What was his level of tolerance toward the missionaries and how did he meet the challenge posed by the settlers who came on their heels? Finally, how did he deal with fellow employees, both subordinate and superior, and how did all of this influence his ability to manage company affairs? In examining such questions, enough is revealed about Dr. McLoughlin to render a favorable impression of the balance of his leadership and make a valid estimation of the impact he had on the history of the Pacific Northwest. 


\title{
THE LEADERSHIP OF JOHN MCLOUGHLIN
}

IN RELATION TO THE PEOPLE AND

EVENTS OF PACIFIC NORTHWEST HISTORY, 1824-1846

\author{
by \\ J. DAVID HOLLIDAY
}

A thesis submitted in partial fulfillment of the requirements for the degree of

\author{
MASTER OF ARTS \\ in \\ HISTORY
}

Portland State University

1996 


\section{INTRODUCTION}

To become immersed in the study of any era of history is to find oneself adrift upon an ocean of names, dates, incidents and facts. As if on a real sea, the waves of documents can hypnotize or make one jaded by the monotony of their relentless rhythm. Whether rounding Cape Horn with Sir Francis Drake or lifting off from Cape Canaveral with Neal Armstrong, the maintenance of an alert and sensitive mind is the challenge of any historian if he or she hopes to shed new light on old material. The mind is aided in this task when it finds a certain event or individual of particular interest on which to focus. Even more stimulating is the new life and color that is immediately breathed into a person from a bygone era when enough detail can be pieced together from available sources to illuminate certain characteristics of his personality. This humanizing quality of what otherwise would be dry, superficial data, allows historical figures to live again, however briefly, if only in the mind of the researcher. Sometimes such individuals attract attention as much for the personality revealed by such research as for the accomplishments they may otherwise be noted for. Such was the case with John McLoughlin.

Much has been written about "The Good Doctor", as he was called by many of those early pioneers who settled the Oregon country. Most of the biographical material, such as that found in the works of Holman, Johnson, Montgomery, and Fogdall is designed to paint as full a picture of the entire spectrum of his life as possible, with understandable emphasis placed on the years that comprised his sojourn at Fort Vancouver. That period, wherein he 
served as chief factor for the Hudson's Bay Company, is often framed and embellished by the bits and pieces of information known of his early years on the one end, and the well documented but sad closing years of his life in Oregon City on the other. The material is usually divided into chapters which sequentially chronicle the events and circumstances in which he was involved throughout the course of his prolific career. Where his name crops up in the historical commentaries of the Pacific Northwest, as in the works of Bancroft, or in the history of the Hudson's Bay Company, as found in the works of Rich, he is seen more as a thread within a giant mosaic, that weaves in and around similar threads of historical figures and events which together constitute the full scope of each particular study. Both of these approaches served as the vehicles which initially drew my attention to John McLoughlin and sparked a desire to know more about him, not merely as an historical figure, but as a socially interacting human being. Where that material served as the spark, the extensive and substantial volumes of the personal and business letters of the man, his family and associates, as found in the works of Barker, Rich and Brown, served as the flame which shed the greatest light on his personal character. As such, he began to emerge, not as one caught in the flow of history, but as an individual whose relationships to the people around him served as the catalyst from which many of the events of that particular era were formed. It is in the acknowledgement that neither history nor historical events create great or significant individuals, but it is unique and significant 
individuals who create history, that has inspired this work.

To become acquainted with the individuals who comprise the pages of history is to come face to face with a seemingly endless parade of tyrants, charlatans, bigots, egotists and power-hungry fanatics. To find the rare person whose behavior could, in any degree, be described as honorable or ennobling, one must usually dig past the princes, magistrates, generals and statesmen. Such characteristics are found most often among those who arise from the unobtrusive masses to heights of heroism or great accomplishment, not from a desire for fame, power, or riches, but usually from a determination to resist or defy overwhelming odds which threaten to alter or extinguish a set of values, a way of life, or life itself. In this the Good Doctor stands out as one who arose from a common background to positions of influence and power through a combination of circumstance and honest effort. What he achieved with that influence and what he did with that power provides a study of one of the most refreshing and truly unique characters in any history.

It was circumstance that placed John McLoughlin at Fort Vancouver, where he managed the affairs of the Hudson's Bay Company for over twenty years. Had he been sent to Fort Colville or the Fraser River, his life and the history of the Pacific Northwest would likely have been greatly different. It was on the Columbia where he would stand between the opposing tides of two nations, caught in the melee of a changing era and way of life. It was under those conditions that he was to face a foe that would not only challenge 
the very fiber of his integrity, but would cause him to sacrifice nearly all of his earthly honors and wealth rather than submit to it. The purpose of this work, using such material as has already been mentioned, is to examine the make of the man himself, including the strengths and weaknesses he possessed as a leader and business manager, as revealed in the varied relationships he had with those he associated with in the course of pursuing his chosen occupation. In so doing, it is hoped that added insight would be afforded into the effect John McLoughlin had on the relatively obscure history of the Pacific Northwest. 


\section{CHAPTER I}

\section{McLOUGHLIN AND THE NATIVE AMERICANS}

Within the realm of American history are many themes that have not only inspired a major portion of American literature, but become so deeply entwined in our national heritage as to often make it difficult for the casual student to distinguish between that which is fiction and that which is not. Among them, and standing next to the cowboy in near mythic status, is the image of the intrepid frontiersman whose mission it was to forge a new nation from a raw and untamed wilderness. Whether studying the exploits of an actual individual such as Daniel Boone or stalking through the forests of our imaginations with Cooper's Leatherstockings, the image has created a lasting impression on the minds of the modern public which in turn has colored our perceptions of the past and created a stereotyped national character.

The image of the buckskin-clad frontiersman with his trusted flintlock cradled in the crook of his arm, silently moving through the woods, is as fixed in the minds of the modern generation of school children as is the one of his modern counterpart planting a flag on the surface of the moon. However, where the alien foe of the latter exists only in the imaginations of Sci-Fi writers and Hollywood producers, the foe of the former was real. What that foe lacked in high tech weaponry, he made up for in lethal cunning and savage ferocity. Against this formidable adversary, the frontiersman was wary of every step he took into the ominous uncertainty of the wilderness. Each 
succeeding generation had to face him as the borders of civilization stretched ever westward with each passing year, until both the land and its native inhabitant were ultimately conquered. From the dark and brooding woodlands of the East, through the vast emptiness of the Great Plains and on to the Pacific, the pattern was repeated again and again. In the doing, it left an imprint on our national character deeper than the wagon ruts of the Oregon Trail.

The whites were successful, according to the formula of the theme, because of their unrelenting determination, the vast resources afforded them through the organized labor of civilization, and in sheer numbers, which swelled with each new generation as settlers followed their dreams to the fertile lands which constantly beckoned them westward. They adapted to the unfamiliar environment and adopted some of the ways of the native long enough to meet both as more than an equal and thereby insure mastery over them. The fact that each task was formidable only strengthened the theme, making the accomplishment all the more awe inspiring.

The other party in this perpetual melodrama, the Native American, was a formidable counterpart. Though no less fearless and determined, he was esteemed to be as wild and unrelenting as the land itself. Indeed, he was considered to be the master of his environment, not by subduing and altering it, but by being an integral part of it. Because of his unwillingness to adapt, or adopt the ways of the white man, his way of life was doomed from the start. 
That he would not yield without a fight, completed the necessary ingredient to the theme and produced both outrage and sympathy among succeeding generations of whites depending largely on the whims of public sentiment, which were in turn often fueled by the extent of its appetite for new land.

There were cases in real life as well as in fiction where members of the two cultures worked together. Oddly enough, it was often the native who acted as tutor and guide to the white man. Names like "Squanto", "Chingatchguk", "Sacagawa" and "Tonto" come readily to the mind of most grade school children, though being confident about which were actual people would not be so easy. Sadly, the results of these alliances, whether in life or in literature, never blossomed or spread to encompass the rest of their races, but ended in an emptiness that only hints at what might have been or what could yet be. Other familiar names like "Tecumseh", "Geronimo", "Custer", "Sitting Bull" or "Little Big Horn" and "Wounded Knee", evoke images which complete the theme and seem to indicate that most encounters between the two races ended in bloodshed. Equally sad, is the fact that it is in these individuals and events that our greatest fascination seems to lie. It is out of the smoke of battle that our heroes are so often born.

The true nature of history is not limited to such common stereotypes. While certain historical figures can be categorized by their heroic achievements which support the above mentioned theme, there are others whose accomplishments are significant yet are not linked with daring deeds, narrow 
escapes or tragic death. That their names are not as common as their more famous contemporaries is more the fault of a public lust for that which is sensational than from any failure on their part. Among such individuals is Dr. John McLoughlin, who served as chief factor of the Hudson's Bay Company at Fort Vancouver from 1824 to 1846 . Though his name is initially more commonly linked with the history of Canada, it was on the Columbia where the history of two nations run together that his influence on United States history is felt. Within that relatively short span of time his contribution to peaceful settlement in the Pacific Northwest was significant. This fact is made all the more interesting when one bears in mind that his responsibility was to promote the business of the Hudson's Bay Company, which inturn would not benefit from the growth of settlement on lands devoted to the acquisition of furs. What makes the man extraordinary is that in attempting to do the latter, he unintentionally did the former and eventually fell from grace because of it. Though he was committed to the productive management of company affairs, he never let the cold numbers in the ledger dictate his handling of human affairs regardless of whether the human was red or white, British or American, fellow company man or competitor. The foremost factor in promoting the success of the fur trade also happened to be one of the most necessary ingredients for promoting settlement. Neither could be accomplished without securing the peaceful cooperation of the native tribes in the territory. That John McLoughlin was able to do so with relatively few incidents of bloodshed is a 
feat worthy of examination. What was his disposition toward the Indian people and why was he so successful in managing a coexistent stream of interactions between them and the whites who came to the area? Did he possess some gift of inborn intuition and sympathy which allowed him to know the minds of the vast and varied tribes of Native Americans and thus elicit their benign cooperation? Or was it more due to the fact that the native was cowed by his striking appearance and forceful manner which, to them, may have symbolized his ability to bring the all-powerful arm of the British Empire to bear upon all who would stand in the path of its bid to strengthen itself as a world power? Then, too, were the tribes of the Pacific Northwest simply less war-like than their brothers of the Eastern woodlands or of the inland mountains and prairies? Whichever the case, the fact remains that during the years of John McLoughlin's influence in the region relations between the Native Americans and the White man were comparatively less violent than those which immediatley preceded or followed him.

The reverence associated with McLoughlin's name is more of a local phenomenon, not because his achievements were insignificant with regard to national history, but more due to the fact that he does not fit the image of the afore mentioned theme. A closer look at the man and his method of dealing with the Native Americans in his sphere of influence reveals an individual of superior insight and management skills as much in the realm of human relations as in those necessary to operate a branch of a business network which 
was only surpassed in scale during the nineteenth century by a relative few. As chief factor of the Vancouver post the "White Headed Eagle", (as he was often called by the Native Americans who knew him) managed one of the largest expanses of territory controlled by the Hudson's Bay Company. It stretched from the Rocky Mountains to the Pacific coast and from the Russian dominated lands in the north to those claimed by Spain in the south. Within those boundaries were numerous tribes, each of whom claimed a portion of the land as their ancestral home. They were as varied in culture as the topography of the lands they lived on and the prestige of their men was measured by their success in carrying out raids against their neighbors. Because the primary business of the $\mathrm{HBC}$ was furs, to a large degree its success depended on eliciting the cooperation of these tribes. The trade network of which the Columbia was to play a major role stretched westward to Hawaii and eastward across the American continent or south around Cape Horn to company headquarters in London. Its rise to power had been neither easy nor peaceful and by the time John McLoughlin found a place in its ranks, it had effectively crushed or absorbed a sufficient number of its rivals to enjoy a virtual monopoly. Though it employed an army of trappers, a major portion of its business depended on trade with the indigenous tribes of the lands it controlled. The post at Fort George, located at the mouth of the Columbia River, in the Oregon Territory, not only was responsible for the largest amount of land, but also the greatest number of tribes. Neither the land nor the 
trading rights were the exclusive possession of the Hudson's Bay Company, however. A convention signed in 1818 by the United States and Great Britain allowed joint occupancy of the land to members of their respective nations who desired to settle or pursue business there. The arrangement was renewed in 1827.1

Though both nations were in competition and sought ways to strengthen their influence, because of the presence of the HBC and its resident chief factor, the scales were tipped heavily in favor of Great Britain. This placed John McLoughlin in the powerful position of being the social, commercial and judicial "monarch" of the region. Very little that transpired within its borders escaped his watchful eye.

Not only did Chief Factor McLoughlin assume the responsibility with vigor, but the results of his management skills were quickly apparent. He turned around a business riddled with mismanagement and began negotiating with the Indians in a manner calculated to enhance the effectiveness of company affairs. S.A. Clarke, who made his migration across the continent on the Oregon Trail in 1850, and knew the doctor personally assesses him in the following manner:

He understood the Indian character and ruled it on natural principles. He made them believe he respected them, and that made them believe in and respect him. ... He had to be an exceptional man to meet the demands upon him, both to control

${ }^{1}$ Frederick V. Holman, Dr. John McLoughlin, (Cleveland: The A. H. Clark Company, 1907), 21. 
the natives of the imperial west, as well as for the government of the often reckless creatures who were employees of the Company, including French-Canadians, Scotchmen, Orkney Islanders, Irish, Iroquois from the Canadian Indians, free trapping Americans, mountaineers and Kanakas from the Sandwich Islands. ${ }^{2}$

Whether or not this is an accurate picture of his relations with the Indians, it does indicate that besides managing affairs with them the doctor had his hands full with those employed by the company itself.

Though tribes throughout the Oregon Country were familiar with the craft of warfare, trade was the primary way of life among those of the Pacific Coast. At their center were the Chinooks, whose strategic possession of the lands flanking the mouth of the Columbia River made them the effective middlemen between coastal and inland tribes. Though it was to the advantage of all the Northwest tribes to be on peaceful terms with their neighbors, inter-tribal feuding was not uncommon ${ }^{3}$ as with the feud between Comcomly and Casino which will be mentioned shortly. More tenuous were the interactions with the European and Russian explorers, whose vessels had been appearing in coastal waters in increasing numbers during the latter decades of the eighteenth century. Stories of shipwrecked crews being murdered or placed into slavery were common, if difficult to corroborate, but the logs of many of the early explorers reveal incidents of open hostility. Bruno de Hezeta, for example,

${ }^{2}$ S.A. Clarke, Pioneer Days in Early Oregon, Vol. I, (Portland, J.K. Gill Company, Burlington Printing House, New York, 1905), 209-210.

${ }^{3}$ Robert H. Ruby and John A. Brown, The Chinook Indians, Traders of the Lower Columbia, ( Norman: University of Oklahoma Press, 1976), 175. 
while going through the formalities of placing a Spanish claim at what is now Point Grenville on July 14,1775, encountered natives with whom interactions quickly soured. Appearing friendly enough at first, they displayed skins they had apparently brought to trade. However, a detachment of the crew who went ashore from the Sonora, the attendant vessel under the command of Juan de Francisco de Bodega y Quadra, were attacked and killed during their attempt to obtain fresh water from the Quinault River. The Indians then attempted to surround the vessel in their canoes, but a volley from the ship's guns killed six and put the remainder to rout. ${ }^{4}$ News of this incident was quick to spread through both cultures and would leave a legacy of fear and distrust for years to come.

With the arrival of Robert Gray on the Columbia River on May 11, 1792, a new era of trade relations opened between the two races that had a major effect on both. Not only did it put the maritime traders in touch with one of the most influential tribes on the Pacific Coast, but it placed the Chinooks in a significant position within the great triangular trade route that stretched from Boston and other East coast ports, to the Pacific Northwest and on to the Orient. Gray sold his first load of furs in Canton for $\$ 21,404.71 .^{5}$ It was not

${ }^{4}$ Herbert K. Beals, ed., For Honor and Country, The Diary of Bruno de Hezeta, (Portland: Western Imprints, The Press of the Oregon Historical Society, 1985), 78.

${ }^{5} \mathrm{~J}$. Richard Nokes, Columbia's River, The Voyages of Robert Gray, 17871793, (Washington State Historical Society, published in conjunction with the 1992 International Maritime Bicentennial), 123. 
long before vessels manned by "King George Men" (Englishmen) and "Boston Men" (Americans) were crossing the treacherous bar with increasing frequency. The next one to do so was the Ienny, a three masted schooner from Bristol, England, piloted by Captain James Baker. Though the British were to claim that he actually beat Gray to the river, the Chinooks maintained that the Americans were the first to cross the bar. ${ }^{6}$

Before leaving the river, the Jenny was joined by the 135-ton brig Chatham, commanded by Lieutenant William Robert Broughton, whose orders were to explore the river and take possession of its tributary lands. Their initial interactions with the Chinook were friendly. However, as Broughton carried out his orders, sailing upriver in a launch with part of the crew and two weeks' worth of provisions, the relations became increasingly chilly. By the time they reached the point where Fort Vancouver would one day stand, the situation with the Indians, who had followed along in their canoes in large numbers, had become quite tense. Further exploration attempts were abandoned and the men returned to the Chatham, which lay at anchor back downstream. ${ }^{7}$

The peak of difficulties in the pre-Mcloughlin era came with the loss of the American Fur Company vessel Tonquin, off the coast of Vancouver Island in

${ }^{6}$ Ruby, 53.

7J. Neilson Barry, "Columbia River Exploration, 1782," Oregon Historical Society Quarterly, vol. 28, (March 1927), 144. 
the summer of 1811. Although a new phase of trade had opened with the emphasis switching from maritime to land-based entrepreneurs, ocean going vessels were still essential to the overall success of the enterprise. When news of the disaster reached the inhabitants of Fort Astoria through local Indians, it was given little credence. greatly feared that such an act would embolden the local tribes, whose cooperation they depended on. As subsequent reports seemed to verify that it was true the Astorians began to fear that such an act would embolden the local tribes, whose cooperation they depended on. "The Indians of the Bay looked fiercer and more warlike than those of our neighborhood," wrote Gabriele Franchere, an eye-witness to events at the fort, "so we redoubled our vigilence and performed a regular daily drill to accustom ourselves to the use of arms. To the necessity of securing ourselves against an attack on the part of the natives was joined that of obtaining a stock of provisions for the winter."8 Even if they were to be spared a similar fate as the ship and her crew, if the Indians became belligerent, they might still be put out of business. ${ }^{9}$ Preparations for defense continued through the summer.

During the whole month of July, the natives (seeing us weakened, ... ) manifested their hostile intentions so openly that we were obliged to be constantly on our guard. We constructed ways inside our palisades and raised our bastions or towers another story. The alarm became so serious toward the latter end of the month that we doubled our sentries day and night, and never allowed more than two or three Indians at a

${ }^{8}$ Gabriele Franchere, A Voyage to the Northwest Coast of America, ed. Milo Milton Quaife, (New York: The Citadel Press, 1968), 87.

${ }^{9}$ Ruby, 135. 
time within our gates. ${ }^{10}$

Their fears, happily, were to prove unfounded, and peaceful interactions with the Chinooks and their venerable old chief, Comcomly, continued. It would be many years, however, before the shadow cast by the massacre would be lifted.

Little had such conditions changed when Dr. McLoughlin arrived on November 9, 1824. So crucial was it that the new chief factor get off on the right foot that Governor George Simpson made the journey himself overtaking McLoughlin's party well before reaching the Pacific. Though the two men did not see eye to eye on all matters each had the success of the company as their common goal and were thus able to work together. Besides their eventual agreement to move the post upstream, they also concluded that productive relations with the natives would play a major role in the overall success of the business in the Pacific Northwest. The approach taken toward achieving that objective by Dr. McLoughlin would demand all the past knowledge and experience he had previously acquired of the Native Americans and their culture as well as that which he was presently attaining. ${ }^{11}$

At what point in his life John McLoughlin became acquainted with the Indians is uncertain. Growing up as a boy in Riviere du Loup, on the banks of

${ }^{10}$ Ruby, 118.

${ }^{11}$ Robert C. Johnson, John McLoughlin, "Father of Oregon", (Portland, Ore: Binfords \& Mort, 1958, c1935) 27. 
the St. Lawrence River, would surely have put him in a position to observe the comings and goings of the local native tribes who commonly used the waterway. His early life brought him into contact with a wide variety of cultures and life styles. Much of this social education was gained from the frequent visits he made to the residence of his paternal grandfather Malcom Fraser, who lived several miles away at Mount Murray. It has been suggested by some biographers that it was there that he and his brother David first came under the influence of their flamboyant Uncle Simon, who had served with the Black Watch as a surgeon until 1801 when he was wounded in an engagement in Egypt. Thereafter he left the army and settled in Terrebonne near Montreal. ${ }^{12}$ It is also suggested that the periodic homecomings of Uncle Alexander, a fur trader for the North West Company, left an equally strong impression on the young McLoughlin. There is some doubt, however, that Uncle Alexander's vacation schedule ever coincided with the boy's presence at Mt. Murray, but it is relatively certain that young John was as easily influenced by hearing stories about his uncle as he may have been had he actually been in his company. In any event, it is likely that here was the boy's introduction to the fur trade as a possible career. Though he became a certified physician at an early age, when, in 1803, the opportunity presented itself to secure a position with his uncle's employers, he made the step,

\footnotetext{
${ }^{12}$ E.E.Rich, ed.
} 
apparently without much deliberation.

Because much of the commerce in furs brought the company into contact with the Native Americans it is natural to assume that as a "Nor' Wester", the young doctor began to acquire an understanding for dealing with them as he visited the numerous company posts and the different tribes who frequented them. ${ }^{13}$ This experience may have proven equally valuable in schooling him on the successful management of a business in the remote reaches of a wild frontier. Though he became familiar with the operation of the fur trade at the various posts, it was at Fort William where he spent most of his early years in service, and it was after the manner of this outpost that he was to model Fort Vancouver some twenty years later. ${ }^{14}$

As invaluable as the knowledge he gleaned at the different forts was, the single element that taught him the most about the Indian culture was undoubtedly the fact that he married into it. Frontier life was difficult for any but the hardiest of individuals and few white women were willing to leave the trappings of civilization for the lonely and arduous life on a frontier outpost. Consequently marriages between Indian women and white fur traders were common. T.C. Elliott suggests other advantages for white men to marry Indian women. He indicates that the life in a wilderness occuppied by

${ }^{13}$ Rich., xxxii-xxxiii.

${ }^{14}$ Richard C. Montgomery, The White Headed Eagle, John McLoughlin, Builder of an Empire, (Norwood: The Macmillan Company, 1934), 24. 
"Indians of various tribes and dispositions involved personal dangers against which the presence of a native wife and family was a great protection." It also brought them business that would "otherwise pass them by" and afforded them the opportunity to become acquainted with the "language and habits of the people." 15 To this Hussey adds that a "daughter of the country" knew which berries and roots were edible. She could tan deer hides and ake lodge coverings and clothing for them. She could fashion moccasins and snowshoes, items consumed in large quantities and essential for fur trade travel. She was able to patch and gum canoes, as well as make pack cords and saddle bags. She knew how to clean, dry, and pack furs. In addition to all this she performed the domestic chores of the household, both at the trading post and on the trail. ${ }^{16}$

The benefit of such an arrangement was not all one-sided. Marriages to a whiteman offered greater security from starvation and intertribal warfare, and promised greater access to metal utensils, beads and jewelry. "Above all," writes Hussey, "such unions brought increased status for the Indian women and improved trade possibilities for her relations."17

John McLoughlin's marriages were in keeping with this tradition. Little is known of his first wife other than the fact that she died while giving birth to their first son, Joseph. ${ }^{18}$

${ }^{15}$ T.C. Elliott, "Margaret Wadin McKay McLoughlin", Oregon Historical Society Quarterly, Vol. 36, (December 1935 ), 345.

${ }^{16}$ Hussey, "The Women of Fort Vancouver", Oregon Historical Society Quarterly, (Fall 1991), Vol. 92, No. 3, 266.

${ }^{17}$ Ibid.

${ }^{18}$ Clarke, 192. 
The doctor's second marriage was to Margaret Wadin McKay, whose father, Etienne Wadin, a fur trader from Switzerland, and whose mother, Marie-Joseph Deguire, was believed to be either full blooded or half Chippewa. It was Margaret who was to be the doctor's life-long companion and who would stand by him as counselor and comforter in the eventful years that lay ahead. Though the date of their union is "not definitely known," states Robert Johnson, it "may be approximated by the birth of their first child, August 18, 1812."19 There is debate among some historians as to whether the date of her marriage allowed a sufficient mourning time from the death of her first husband, Alexander McKay, a well known figure in the history of the fur trade and of the NWC, who died aboard the Tonquin in 1811. Hussey, on the other hand, believes that McKay and his wife were seperated due to the fact that she and McLoughlin were obviously married before news of McKays death could have reached them. ${ }^{20}$ She brought three daughters and a son with her from her first marriage. Details regarding her meeting and subsequent courtship with McLoughlin are unknown.

The union of John and Margaret opened a new chapter of hope and dedication in their lives, to which they remained faithful to the end. Not only was Margaret to be a pleasant companion, but her gentle manner and sensible approach to life were the perfect counterbalance to the apparent intellectual

\footnotetext{
${ }^{19}$ Johnson, 27.

${ }^{20}$ Hussey, "Women", 272.
} 
skills and emotional disposition of the doctor. She is credited with being a calming influence which greatly offset the displays of temper for which he was famous..$^{21}$ His respectful treatment of her in public was an example to all and was not missed by the American women, who later accompanied their husbands to the Oregon Territory.22

It is the common assumption by some biographers that Margaret had received some formal education in her youth under the tutelage of Ursuline nuns. T.C. Elliott, however cites ample evidence from recorded documents that she was unable to write her name, and in affixing her signature always used the simple $X_{.}^{23}$ Regardless, she was known for her gentle nature which together with the fact that she was nine years the doctor's senior, helped her to become a source of strength and wisdom to which he would turn for counsel again and again. Not only would she follow him to the far end of the continent, but she was unsurpassed in her loyalty and selfless devotion.

Besides her devotion to her husband, Margaret was known for her humility and service to others. She was, for example, a help to other Indian women in making the transition to life with a white husband by training some of them in the arts of keeping house. ${ }^{24}$ She also demonstrated a motherly

${ }^{21}$ Johnson, 120.

${ }^{22}$ Ibid.

${ }^{23}$ Elliot, "Margaret", 342.

${ }^{24}$ Alberta Brooks Fogdall, Royal Family on the Columbia: John McLoughlin and his Family, (Portland: Binford \& Mort, Publishers, 1984), 71. 
disposition toward sick immigrants and sent clothing and food, saying "It is a duty put upon us by our Heavenly Father." ${ }^{125}$ Narcissa Whitman considered her to be one of the kindest women she had ever met. ${ }^{26}$

"As she aged," writes Fogdall, "the 'Indian characteristics' were emphasized. Her short, stout figure and her plain clothes were 'lacking in womanly grace' and all the more unattractive next to his 'straight-as-an-arrow, well-dressed,' tall, erect figure. Nevertheless, he loved her devotedly and treated her chivalrously."27

Of the early years that the doctor spent in the North West Company, one event stands out as significant with regard to his feelings toward the Indians. The second decade of the new century was a tumultuous one in the fur trade. Competition was so fierce that open hostilities had arisen and blood flowed freely in the north woods between rival companies. The peak of hostilities in what was to be called the "Pemmican War"28, was reached late in the summer of 1816 , when a brutal massacre occurred in the Red River region of central Canada. In it, Governor Robert Semple of the HBC and twenty of his men were murdered by a band of mix-blooded trappers, sympathetic to the plight

${ }^{25}$ Eliza Wilson, "Oregon Sketches", quoted by Theresa Gay in Life and Letters of Mrs. Jason Lee, (Portland: Metropolitan Press, 1936), 155.

${ }^{26}$ Hussey, "Women", 272.

${ }^{27}$ Fogdall, 76-77.

${ }^{28}$ E.E. Rich, History of the Hudson's Bay Company, 1670-1870, Hudson's Bay Record Society Series, ( London: Hudson's Bay Record Society,1958-59), 320. 
of the NWC. Though such action was not condoned by the NWC, William McGillivary, the local official, knew that the finger of accusation would be pointed at him. Looking for a place to shift the blame, it was his idea to implicate a local tribe of Indians. Doctor John, would not hear of it and openly stated that no Indian had taken part in the massacre. "He knew well enough that French Canadian half-breeds had committed the crime, and he was not disposed to let innocent red men suffer."29

Further evidence of the emerging character of John McLoughlin is indicated by the events that followed the massacre. An outraged Lord Selkirk of the HBC held the North West Company officials responsible and several, including the doctor, were arrested. They were to be taken for trial, to York Factory, located on the banks of the Hayes River about five miles from Hudson's Bay. While crossing Lake Superior however, the canoe in which John was riding, capsized and most of those aboard were drowned. It was several weeks before he was strong enough to continue the journey. Under house arrest as his health improved it would have been relatively easy for him to escape the clutches of those who sought his conviction. Instead, to his credit, he travelled voluntarily to York Factory in the fall, intent on clearing his name. On the 30th of October, 1818, his case was heard and John McLoughlin was judged to be innocent. ${ }^{30}$

\footnotetext{
${ }^{29}$ Montgomery, 32.

${ }^{30}$ Montgomery, 33.
} 
It is a large step from the court room on the Hayes River to the remote outpost on the banks of the Columbia. The events that transpired during the intervening years saw the doctor travel to London to represent the North West Company in the peace negotiations with the Hudson's Bay Company ordered by Parliament. His leadership skills were apparently significant enough to win the trust of his employers, whose interests he was to represent on this important mission. As the warring factions voted to merge interests, George Simpson of the $\mathrm{HBC}$ was approved to be the acting governor of the enterprise in Canada and Dr. McLoughlin was nominated as one of the new chief factors. His deportment during his years of service with the NWC and at the negotiations had not missed the eyes of his new employers, who sought to utilize his leadership and business skills in the revitalizing and expanding of their base of operations. He returned to Canada and assumed his first post at Fort Francis, located along the banks of the Peace River in Northwest Central Canada. After serving faithfully for two more years, he was summoned to York Factory for the annual council meeting in the summer of 1824 and on the 10th of July he was reassigned to Fort George to replace Alexander Kennedy, who had been serving there as chief factor since 1822. Production at the remote post had waned significantly over the past years and it was hoped that a positive change could be made with the infusion of new blood. Named to serve with the doctor as chief traders were John W. Dease, John McLeod and 
Peter Skene Ogden. ${ }^{31}$

With his arrival on the Columbia, the White Headed Eagle was soon to make his presence felt. With the assistance of Governor George Simpson he immediately set about the task of improving the business capabilities of this lonely but strategic outpost. According to Hussey, the Columbia department was regarded by the Governor and Committee of the $\mathrm{HBC}$ as primarily a defensive zone for the protection of the interior with the secondary hopes that it could "produce a profit." ${ }^{32}$ The growing dispute between the United States and Great Britain regarding the region caused the latter to consider ways to fortify their claim north of the river, which they assumed would one day be the defining border which would seperate their respective interests. Hussey also points out that according to the Treaty of Ghent, which effectively ended the War of 1812, Fort George was to be returned to the Americans whenever they wished to claim it, and this was one of the reasons for the lack of effort in maintaining either the physical structures at the Fort or an enthusiasm for trade. ${ }^{33}$ Shortly after the arrival of Simpson and McLoughlin the decision was made to relocate on the north shore at a site which would allow them to be independent of foreign aid. ${ }^{34}$ McLoughlin and Alexander Kennedy were

\footnotetext{
${ }^{31}$ Hubert Howe Bancroft, History of the Northwest Coast, (New York: The Bancroft Company, 1884), Vol. I, 485.

${ }^{32}$ Hussey, History, 22-23.

${ }^{33}$ Ibid., 24.

${ }^{34}$ Hussey, History 38.
} 
dispatched to find a suitable site, but it wasn't until they "passed the mouth of the Willamette and approached the vicinity of the present city of Vancouver" that they found "what they had been seeking." 35 The site chosen was suitable not only because of its accessability to the Columbia river, but also to the Willamette. The fertile soil at what was to be called Fort Vancouver made the decision to move all the more easy. ${ }^{36}$

Equally as drastic as the move, was their commitment to eliminate the sale of liquor to the natives. It was not going to be an easy task and would be one that the doctor would have to monitor for years to come. In a letter from Vancouver written on the 20th of October, 1831 he made the following observations:

I certainly wish for my part that means could be found to put a stop to the sale of Liquor to Indians (and also of Arms and Ammunition to those on the N.W. Coasts---as they do not absolutely require them to procure their food) as Besides the Actual Injury Liquor does them I will say as far as my Experience goes that it is injurious to the Regular trader and Only Advantageous to An Opposition as being liberal in Liquor is the Easiest---Cheapest and quickest means---It has to acquire influence over Indians. ${ }^{37}$

It was the agreed upon assumption between Governor Simpson and Chief Factor McLoughlin that liquor "tended to deprive Chinooks of the will and wherewithal to continue their role as dealers and agents to the various
${ }^{35}$ Ibid., 38-39.
${ }^{36}$ Fogdall, 60.
${ }^{37}$ E. E. Rich, Letters, First Series, 232. 
tribes." ${ }^{138}$ Simpson went on to say:

... if they were allowed to Drink the Value of the Furs they bring they would not have the Means of continuing Barter and we should be the sufferers in the long run; but in order to ensure good and constant returns and extend the trade we must endeavor to encourage the consumption of Woolens and other useful British Manufactures which will in due time become necessary to the Natives from habit, when they must and will work to supply their wants ... ${ }^{39}$

The decision to eliminate alcohol from the fur trade was to be an earmark of the administration of John McLoughlin throughout his tenure in office and though challenged continually, he never faltered in his resolve. Undoubtedly his regulation of the liquor traffic was a major factor in his ability to maintain productive and workable relations with the natives. In this he was aided by the one-eyed Chinook chief, Comcomly, who was well aware of the harmful effects of trade rum on his people. According to Ruby and Brown, it was hard for the Indians to understand the concept of moderation. If a little of something was a good thing then it stood to reason that a lot of it was "proportionately better". ${ }^{40}$ Even more confusing was the apparent desirability of the offending substance to the white men themselves. "You tell us that rum is no good," observed a Chinook to one of the American traders, "but you take a tolerably fair quantity yourself." ${ }^{.11}$ McLouglin's greatest threat to the success

$$
{ }^{38} \text { Ruby, } 173 .
$$

${ }^{39}$ Frederick Merk, ed., Fur Trade and Empire, George Simpson's Journal, (Cambridge: The Belknap Press of Harvard University Press, 1968), 110.

${ }^{40}$ Ruby, 191.

${ }^{41}$ Ruby, 191. 
of his mission came from fellow white men. The fact that the American traders did not endorse his wishes did not dampen his determination to halt its sale and on at least one occasion he purchased the entire cargo of a Yankee vessel in order to keep the offending spirits out of native possession. ${ }^{42}$

Though the goals of Dr. McLoughlin regarding the natives did not include converting them to the white man's culture, he did use every opportunity to teach them principles that were more in harmony with it. Responding to an accusation leveled by Captain William Slacum, who had been sent by the United States government to investigate $\mathrm{HBC}$ activities in Oregon in 1836, the doctor wrote the London office:

It is incorrect that we encourage Slavery and on the reverse we avail ourselves of every opportunity to discourage it. Tho' we cannot prevent Indians having Slaves We tell the Masters it is very improper to keep their fellow beings in Slavery: moreover we have redeemed several and sent them back to their own Country this very season. Some Indians of this vicinity had captured two families in the Willamette or as they express themselves made slaves of them. By our influence they were liberated but strange as it may appear there are instances in which the slave will not return to their lands and without laying claim to doing more than our duty we can say that our influence has vastly ameliorated the situation of the slaves in every part of this Country, in which we have been. If the plan we adopt is followed they will before long emancipate themselves. ${ }^{43}$

Bancroft suggests that the doctor had "a just appreciation of the Indian character. In his eyes a savage was never a monster, but a man, the offspring

\footnotetext{
${ }^{42}$ Bancroft, Vol. II, 435.

${ }^{43}$ Rich, Letters, Third Series, 271.
} 
of our common mother nature." ${ }^{14}$ This is an interesting statement from a man who ascribed to a belief held by many in the 1880 's, that the white race was superior to all others. He could not understand why such men as McLoughlin could assent to marrying Indian women: "Surely they were possessed of sufficient intelligence to know that by giving their children Indian of half breed mothers, their own Scotch, Irish, or English blood would then be greatly debased." 45

The first Northwest native that the doctor had become well acquainted with was Comcomly. The old chief had been disappointed at the decision to abandon Fort George. Matters were complicated by a near outbreak of hostilities between Chinooks and Clatsops, and post officials slowed their efforts to remove goods for fear that the natives near the fort would be incited to begin looting. The rumor of an approaching American man-of-war urged them on, however, and though it was company policy to halt work on Easter Sunday, John Work and Chief Post Trader Donald McKenzie labored anyway in an attempt to expedite the removal. The building of Fort Vancouver not only took the trade from Comcomly's doorstep, but placed it in the lap of Casino, an up-river chief, with whom he was feuding. Though Dr. McLoughlin had extended an invitation to Comcomly to trade at the new fort, Casino had other plans. Here was his chance to achieve exclusive status

\footnotetext{
${ }^{44}$ Bancroft, Vol II., 434-5.

${ }^{45}$ Ibid., 650-653.
} 
among the whites if he could keep the downriver Indians away. It was his intention to use force if necessary. This new twist in their power struggle only served to intensify the jealousies and ill feelings that already existed.

Consequently, not long after the doctor's assumption of his new assignment, he found himself embroiled in a native power struggle:

Guarding his newly found importance, Casino raised a fuss because the company had assured Comcomly's passage upstream beyond his village some six miles below Fort Vancouver on the Columbia north shore to trade with the British. Now chief factor at Fort Vancouver, McLoughlin warned Casino that the company could not stand by and let his guns obstruct Chinook flotillas enroute to the fort. A big man in most ways, McLoughlin spoke with the authority of his understanding of the native mind gained from experience in the trade that had consumed nearly half of his forty one years. ...believing the Comcomly-Casino feud to have blocked nine-tenths of the native trade that summer (he) diligently sought to effect a truce between the contending parties. In this he was apparently successful. ${ }^{46}$

Not all of the natives were as easily convinced of the power or authority the "White Headed Eagle" had behind his words. Nor were they as easily pacified. For a time the tribes who had been troublesome in the past continued their unpredictable behavior. The doctor's strategy was to establish a policy of immediate reprisal for any hostile act perpetrated against any white men regardless of what company or country they represented. In 1828 he sent a detachment of troops from Vancouver to punish Clallam Indians who had 
murdered five company employees. ${ }^{47}$ The following year saw a similar punitive action ordered against the Clatsops, whom he suspected of murdering the crew of the company vessel William and Ann, which had broken up while crossing the Columbia bar. A fifty man detachment under Chief Factor William Connolly, was sent to recover the shipwrecked goods taken by the Indians, who claimed they had a legal right to any bounty given them by the sea. In a letter to John Dease at Fort Colville, dated July 4, 1829, the doctor described the events which followed:

Messrs (William) Connolly (Samuel) Black (John) Work (Francis) Ermatinger \& (John) Harriott with sixty men paid a visit to the Clatsops to demand restitution of the property they secured from the wreck of the William \& Ann but instead of getting this they were insulted. when they attacked the natives Killed four and destroyed their Village the rest saved themselves by flight and I have the satisfaction to say not one of our people got the slightest wound ${ }^{48}$

A letter sent to his superiors, dated August 5, 1829, was more thorough in its coverage of the incident, no doubt penned as much in a spirit of justification as in one of information. In it he stated that he had "deferred," taking such punitive measures for the crime, "till we had more authentic information of its being perpetrated..." After describing how they had recovered five bodies of the crew he concluded, "It remains for me to observe

${ }^{47}$ Francis Ermatinger, "Earliest Expeditions Against Puget Sound Indians", Washington Historical Society Quarterly, vol. 1, ( January 1907), 16-29.

${ }^{48}$ Burt Brown Barker, ed., Letters of Dr. John McLoughlin, Written at Fort Vancouver, 1829-1832, (Portland: Binfords \& Mort, 1948), 18-19. 
in this regard to this melancholy event that I am of the opinion the crew was murdered." 49

A further example of the doctor's disposition to award a punishment befitting the crime is found in a letter written to William Connolly on July 2, 1830. In it he not only affirms his disposition toward punishment, but also indicates the nature of justice that should be afforded any man.

I was informed here this summer (But in the hurry and Bustle I forgot to mention it) that $\mathrm{Mr}$ [William] Kittson had offered two Horses to get an Indian Killed [La Souris?] will you have the Goodness to state to Mr Kittson that the Company will not allow such proceedings and that it must not be done--It is only when Indians have murdered any of the Companys Servants or any persons belonging to the Establishment that we can have a Right to Kill the Murderer or get him Killed ${ }^{50}$

The stern policy of reprisal established by the doctor was not missed by the tribes who were in close proximity to Fort Vancouver. Neither was his inborn sense of fairness. Gradually they began to realize, that in spite of the fact that he wanted peaceful relations with all tribes, there would be no crime that would go unpunished. Equally as powerful was the fact that his actions and words were in concert with his impressive appearance. His towering stature, flowing white hair and piercing gray eyes must have been aweinspiring in a day and age when the common height of white men was between $5^{\prime} 8^{\prime \prime}$ to $5^{\prime} 10^{\prime \prime}$ and the height of coastal Indians proportionately lower.

\footnotetext{
${ }^{49}$ Barker, Letters, 21.

50Ibid., 109.
} 
Frederick Holman's super-human description of the doctor is in marked contrast to that of George Simpson, which will be given later, but carries enough in common with it to create an image to contemplate.

Physically Dr. McLoughlin was a superb specimen of man. His height was not less than six feet four inches. He carried himself as a master, which gave him an appearance of being more than six and a half feet high. He was almost perfectly proportioned. Mentally he was endowed to match his magnificent physical proportions. He was brave and fearless; he was true and just; he was truthful and scorned a lie. The Indians, as well as his subordinates, soon came to know that if he threatened punishment for an offense, it was as certain as that the offense occurred. He was absolute master of himself and of those under him. He allowed none of his subordinates to question or to disobey...and yet with all these dominant qualities he had the greatest kindness, sympathy, and humanity. ${ }^{51}$

Time and distance would prove to be little hindrance as the doctor sought to extend his influence into every corner of his domain. The expedition against the Clallams, which left Vancouver on the 7th of August, 1828, was to travel to Port Townsend on Puget Sound, where the tribe lived. In reporting the event to London, he justified his order as avenging the death of Alexander McKenzie and other $\mathrm{HBC}$ employees. Included in his report was the news that the Indian village had been burned and "the murderers were punished."

I have been particular in giving your Honors the detail of our proceedings in this unfortunate affair as it is a subject on which perhaps there may be a diversity of opinions. It is cerainly most unfortunate to be obliged to have recourse to hostile measures against our fellow beings but it is a duty we owed our murdered Countrymen \& I may say we were forced by necessity, as had we passed over the atrocious conduct of their Murderers, others by

${ }^{51}$ Holman, 25-26. 
seeing them unpunished would have imitated their example \& whenever an opportunity offered have murdered any of us that fell in their way, \& I beg to assure your Honors that before I decided on this measure I gave it every consideration its importance deserved but the more I reflected the more I was convinced of the necessity of our acting with energy, \& nothing but the urgency of the case obliged me to act at once \& prevented my waiting for instructions on the subject. ${ }^{52}$

Three days after the above letter was written the doctor was roused from his office by the news that local Indians had brought a bedraggled and exhausted white man to the fort. He gave his name as Arthur Black, an American, who claimed to be the sole survivor of a nineteen man party of trappers lead by the well-known trader, Jedediah Smith. The story he related detailed his harrowing escape from the scene of the brutal massacre. It had occurred while the party was temporarily camped at the Umpqua River while seeking a route through the coastal mountains which would enable their return with their furs to the Great Salt Lake. McLoughlin's first act was to reward the Indians who rescued the trapper..$^{53}$ The next morning he sent Indian runners bearing tobacco to the Willamette chiefs, requesting their assistance in locating any of the party who may have escaped. He promised a reward to whoever found them alive and added a stiff warning against any who would do further harm. ${ }^{54}$

When Smith and two of his company straggled into the fort the next

\footnotetext{
${ }^{52}$ Rich, Letters, First Series, 65.

${ }^{53}$ Johnson, 83.

${ }^{54}$ Montgomery, 127.
} 
afternoon on their own accord, the surprised doctor greeted them warmly. Though they were Americans and rivals in the fur trade, he saw to their immediate needs with compassion. He instinctively liked his hapless, yet colorful guest ${ }^{55}$ and began formulating plans to assist in reclaiming his stolen furs.

Knowing well the great inter-tribal communication network among the natives, he decided on a tactic that would ensure the secrecy of the expedition's intent. Fearing that open orders to the fifty-man detachment sent to locate and recover the furs might be leaked to their Indian wives and subsequently reach the ears of the culprits, he gave his instructions in a sealed envelope to the leader, John McLeod, with orders not to open it until they had reached the Umpqua. The plan worked inasmuch as the party arrived safely, and quickly located the merchandise. The Indians, whose unhappy lot it was to relinquish them, claimed that they knew nothing of the massacre and had purchased the furs "in good faith" from another tribe. That this indeed may have been the case, became evident when news of hostilities between the two tribes reached Vancouver shortly after McLeod's return with the furs. In all, nearly $\$ 3200$ worth of merchandise was reclaimed, and the Indians of Southwest Oregon learned that there was one as far away as Vancouver who

${ }^{55}$ T.C. Elliot, "Dr. John McLoughlin and His Guests", Washington Historical Society Quarterly, Vol. 3, No.1, (October 1908), 66. 
was capable of exacting justice upon them. ${ }^{56}$ John McLeod's handling of the affair was consistent with McLoughlin's Indian policy of only resorting to hostilities when wisdom and circumstance demanded it.

Douthit, on the other hand, argues against the views that the doctor and the Hudson's Bay Company's Indian policy was based upon their determination to satisfy a mutual desire for furs, avoid warfare and allow the preservation of Indian lands. It is his contention that Company attitude was more hostile, Indians of the region were more docile than believed by most whites, and that the aggressive pattern established by McLoughlin preceded American encounters. ${ }^{57}$ In refering to the Slacum and Spaulding reports to Congress in the late 1830's which charged the HBC with inciting Indians to kill Americans, he further contends that the Indians resented the HBC's coming into their territory for beaver and that the first Americans entering into the region faced hostilities because of the anymosity already felt toward whites. ${ }^{58}$

Reid, on the other hand, contends that the "customs and conduct that developed among fur trappers of the North American Far West left little margin for considering circumstances, granting mercy, or weighing mitigation of liability." He goes on to state:

${ }^{56}$ Dr. John McLoughlin, "Autobiographical Sketch", Oregon Pioneer Association Proceedings.

${ }^{57}$ Nathan Douthit, "Hudson's Bay Company Relations With Southwest Oregon Indians", Oregon Historical Society Quarterly, Spring, 1992, Vol. 93, No. 1, 26.

${ }^{58}$ Tbid., 54. 
if a member of an Indian nation killed either an American or British mountain man, the manslayer (one who commits homicide), or some other member or members of his nation, would be killed in retaliationof-blood. If vengeance were not exacted, and the manslayer or his nation were not "punished," the fur trappers, according to both the legal theory and their expectations would be exposed to further insults and more homicide. ${ }^{59}$

According to Reid, in regards to the Umpqua incident, it was likely the Americans brought on their own misfortune. Upon interviewing the Kalawatsets, who committed the massacre and another neighboring tribe with whom the booty was subsequently traded, McLeod learned that the Americans had acted imprudently and aggressively in trying to exact the return of a stolen axe. There were other circumstances which included an attempted rape of an Indian women and the ordering of a ranking brave to dismount from an American horse he had innocently climbed onto. The Indians told him that they had also become suspicious of the Americans, who openly asserted that "they would soon monopolize the trade and turn us out of the country." 60 When questioned later about the validity of such a claim, Smith responded that he did not doubt it, but that it had been done without his knowledge. The fact that McLeod did not take any hostile action against the Indians for the massacre attests to the fact that the HBC was not out to wantonly shed Indian blood. Concluding that "certain unfriendly aggressive acts committed

${ }^{59} \mathrm{John}$ Phillip Reid, "Restraint of Vengeance: Retaliation-in-Kind, Use of Indian Law in the Old Oregon Country", Oregon Historical Society Quarterly, Spring 1994, Vol 95, No. 1, 49.

${ }^{60}$ Tbid., 80. 
by the Americans were the cause. . he only demanded the return of the property."61 In this and similar behaviors demonstrated by fur traders, they were only acting in accordance with the traditional laws already established by the Indians themselves. Reid then concluded that, "officers saw more risk in not taking appropriate vengeance than in taking it." ${ }^{12}$ Such reasoning would support the premise that the risk of starting a war by exacting timely vengeance was the lesser of two evils and a gamble worth taking. To let the offence go unpunished would only ensure a continuation of hostile acts in the future.

McLoughlin, in concluding that Smith's men, by careless inattention to safety, had been a cause--if not thee cause-- of the attack that took their lives, had arrived at a conclusion rare for a white person in nineteenth century North America or Great Britain. Indeed, the argument could be extended even further: The rule that the American trappers were the responsible agents relieved the Kalawatsets of some, if not all, culpability. When such matters were determined, it was because white perceptions were "shaped to a discernable extent by Indian ways of thinking." That's why McLeod forced all Indians to return the property-not only Kalawatsets but from all other Indians to whom the Kalawatsets had bartered it. ${ }^{63}$

In 1843, McLoughlin responded to charges against himself and the

Hudson's Bay Company by stating:

Having by our system of management, and practical intercourse, subdued the ferocity of the Indian tribes, converted their former hostility against the whites into feelings of respect and attachment, introduced order, and a respect for property, and moral obligation

\footnotetext{
${ }^{61}$ Reid, 81.

${ }^{62}$ Ibid., 82.

63ibid., 85.
} 
which did not before exist among them ... the British of American Government have only to send an Officer with a commission in his pocket, to have their authority acknowledged and maintained. ${ }^{6 t}$

Bancroft observes that McLoughlin and the Hudson's Bay Company policy was one of punishing them when they committed a crime and rewarding them when they deserved it. ${ }^{65}$ Regardless of how true this was, the fact remains that relations with local tribes became friendly to the extent that within a short period of time, a village populated by Indians and company employees, some of whom themselves were native or a mixture of blood, arose near the fort. ${ }^{66}$

The fact that Dr. McLoughlin was able to get favorable results from his Indian policy does not mean that all problems vanished over night. A watchful eye ensured that no breech of his system of order was allowed to go unattended and spread. In a letter addressed to George Simpson, on the 20th of March, 1830 and in another addressed to Simon McGillivary, dated February 27,1832 , he described regrettable incidents that had transpired involving crime and punishment. The former letter dealt with the case of the Indian wife of Chief Trader Francis Ermatinger, who was lured into unfaithfulness by another Indian and the latter letter was penned in response to McGillivary's request for counsel on how to proceed in regards to a local Indian who had murdered his own slave. McLoughlin's responses reveal as

\footnotetext{
${ }^{64}$ E.E. Rich, Letters, Second Series, 185.

${ }^{65}$ Bancroft, Vol. II, 435.

${ }^{66}$ Ibid.
} 
much about himself as they do of his understanding of native ways.

Mr. Ermatinger's woman ran away with an Indian last Spring and he sent Lolo the interpreter after her and desired him to punish the Indian by cutting the tip of his ear which he did and though in the civilized World such an act will appear harsh and on that account it would be preferable that he had resorted to some other mode of punishment. Still, if the Indian had not been punished it would have lowered the Whites in their Estimation as among themselves they never allow such an offence to pass unpunished. ${ }^{67}$

You know also that although the killing of Sasty is murder yet with these Indians it is considered no greater offence than killing a horse; and perhaps not so bad as the shooting the Cow. God forbid that I would mean to justify Murder, but in dealing with Indians we ought to make allowance for their manner of thinking and if I was addressed on the subject by any of them I would say the Almighty has forbid the shedding of innocent blood and commanded that he who shed man's blood by man shall his blood be shed. and in obedience to this command, if a Chief among us was to Kill a slave that Chief would be killed. But as you have not the means of putting this command in execution you will leave it to the Almighty who will punish the Murderer either in this world or the world to come. But you know well what to say and I only mention this to explain you my view of the case. ${ }^{68}$

Such relations were perhaps surprising to the Indians initially. They "soon responded enthusiastically," states one biographer, and what followed was "an appreciable pick-up in the fur trade." ${ }^{\prime 69}$

The next several years at Fort Vancouver were to see many changes. The ravages of fever thinned the ranks of the many tribes in the area as well as the

\footnotetext{
${ }^{67}$ Barker, Letters, 185.

${ }^{68}$ Tbid.

${ }^{69}$ Montgomery, 88.
} 
HBC itself and the "Good Doctor" had his hands full. "McLoughlin was unremitting in his attention to the sick. His fame spread, and from the Rocky mountains (sic) to the Pacific ocean and from California to Alaska, he was hailed as a great, 'Medicine man.'"170

Entrepreneurs from various walks of life came and went, having failed to break the tightly guarded monopoly held by the ever-alert chief factor. Soon other whites were to arrive in the Oregon country, seeking to exploit very different resources than furs. Not only would these find footholds in their endeavors, but for the most part, they came to stay. The first of these were the missionaries, who came seeking a harvest from the fertile ranks of the native populace and close on their heels were the first immigrants who came seeking a harvest from the earth of the Willamette Valley. Both did their part in marking the path of what was soon to become the greatest frontier highway in America and each of these two groups were to have lasting effects on the future of John McLoughlin and the Native Americans with whom he had done business for so many years. The tide of influence was slowly turning in the Oregon Territory.

Less scrupulous individuals, seeing the threat posed by the growing intrusion of foreign immigrants into a land desired by their own nation, would have looked for and naturally found ways to hinder their encroachment. The Indians, themselves could have been as great a deterrent to settlement in the

\footnotetext{
${ }^{70}$ Johnson, 73.
} 
Pacific Northwest as they were elsewhere in the country, and had he wanted to, the "White Headed Eagle" could have encouraged their resistance either by covert means or by openly refusing to interfere. Neither option was ever considered by the man. Instead, he maintained the same policies as in the past and it is a surety that not only was much bloodshed averted because of it, but peaceful settlement in the region was greatly facilitated as well. One incident, taken from the doctor's own account, will serve as an illustration.

In 1843 about 800 immigrants arrived from the States. I saw by the looks of the Indians that they were excited, and I watched them. As the first stragglers were arriving at Vancouver in canoes, I was standing on the bank, nearer the water here was a group of ten or twelve Indians. One of them bawled out to his companions, "It is good for us to kill these Boston's." Struck with the excitement I had seen in the countenances of the Indians since they had heard the report of the immigration coming, I felt certain they were inclined to mischief, and that he spoke thus loud as a feeler to sound me and take their measures accordingly. I immediately rushed on them with my cane, calling out at the same time, "Who is the dog that says it is a good thing to kill Bostons?" The fellow, trembling, excused himself, "I spoke without meaning harm, but the Dalles Indians say so." "Well" said I, "The Dalles Indians are dogs for saying so, you also," and left him, as if I remained longer it would have had a bad effect. I had done enough to convince them I would not allow them to do wrong to the immigrants with impunity. From this Indian saying that it was The Dalles Indians who said it was go od to kill the Bostons, I felt it my duty to do all I could to avert so horrid a deed. ${ }^{71}$

Later the doctor mentioned that he decided to keep this knowledge of the Indian plan a secret because he "felt certain that if the Americans knew it, these men, acting independent of each other, would be at once for fighting,

${ }^{71}$ McLoughlin "Autobiography", in Clarke, Vol. I, 222. 
which would lead to their total destruction..." Adding to these precautions, he sent boats with men and supplies to The Dalles to assist the immigrants who were temporarily camped there, hoping "that the presence of the Hudson's Bay Company people, and the assistance they afforded the immigrants, would deter the Indians from doing them any wrong, and I am happy to be able to say I entirely succeeded." ${ }^{12}$

In some instances the doctor used his knowledge of Indian superstitions to bring about his desired results. In 1826, the noted biologist, David Douglas, for whom the Douglas fir is named, visited the Columbia. He was prone to taking frequent lone walks into the wilderness tok collect specimens.

Concerned for the welfare of the man while at Fort Colville, McLoughlin informed the local Indians that Douglas was the "grass man", who possessed "great powers over flowers and shrubs." The effect this new had upon the Indians was one that left them in awe of the young Scotsman and consequently he traveled about freely and without fear. ${ }^{73}$

When Dr. McLoughlin felt his ability to insure peace was in jeopardy, he acted accordingly. The Rev. H. K. Hines, a missionary himself, mentions in his book that, as the influence of the missionaries began to wane among certain of the Indians, McLoughlin sought occasion to warn them. Sensing trouble among the Cayuse, he warned Dr. Whitman to move from among them. The

\footnotetext{
72McLoughlin, "Autobiography", 223.

${ }^{73}$ T.C. Elliot, "Guests", 65-66.
} 
events which later transpired between the Whitmans and the Cayuses after the resignation of McLoughlin in 1846 are well documented. Though the circumstances which contributed to the massacre were many, it is not a stretch of the imagination to add to them the removal of the doctor's influence over the Oregon Territory.

Even after his move to Oregon City, the doctor sought to offer counsel intended to assist peaceful interactions with the Indians. In 1847 he wrote to the Secretary of War in Washington $\mathrm{DC}$, urging a post to be established in the Rogue River Valley: "Garrisoned by forty or fifty Men to keep these Indians in Check and the Communication open Between this and Fort Hall and Between this and San Francisco. An Indian Agent ought to be placed at this post with an Indian trader with Goods to carry on the trade with the Indians as the sure Means of Reconciling them to the presence of Whites on their lands."

Regarding the personnel, he further recommended: "As the Agent and Men Ought to Be persons Well Known to the Indians and Respected by them such persons can only be found Among the Rocky Mountain traders and trappers Now Residing on the Willamette ..."74

Though in possession of many of the qualities found to be admirable in the personal arsenals of other men of greater fame and lesser accomplishment, John McLoughlin, in his dealings with the Native American, stands out as one

${ }^{74}$ William R. Sampson, Ed., John McLoughlin's Business Correspondence, 1847-1848, Published in cooperation with the Washington State Historical Society, (Seattle: University of Washington Press), 1973, 66-7. 
whose record indicates no sign of calculated exploitation, removal or extermination. On the other hand, the record does indicate that in all his transactions with them he sought fair, peaceful coexistence and the mutual benefit of enjoying the fruits of their respective labors. The incidents where blood was shed were in keeping with the spirit of reprisal, consistent with Indian law and were calculated to discourage further hostilities. With the inevitability of American immigration he only altered his approach by making allowance for this new factor through accommodation. That he soon became aware of the fact that his efforts were an enhancement to the growth of colonization in the area is evident from his claim that "by the policy pursued by me and the earliest cultivators of the soil of Oregon, mostly foreigners, this country was more easily reclaimed from the Indian and settled by whites, and with less loss of life than any new territory of the United States. ${ }^{175}$

With no campaigns to his credit, nor battlefield trophies to his name, John McLoughlin nonetheless, left a legacy of dealings with the American Indian that few others in similar positions of leadership have equaled.

\footnotetext{
Vol. 1, 8.
}

${ }^{75} \mathrm{John}$ McLoughlin, Oregon Historical Society Quarterly, ( March 1900), 


\section{CHAPTER II}

\section{McLOUGHLIN, MISSIONARIES AND SETTLERS}

"For all coming time we and our children will have uninterrupted possession of this country," mused John McLoughlin to his dinner guest, the Rev. J.L. Parrish. The two friends sat comfortably in the spacious dining Hall at Fort Vancouver in the summer of 1840 , contemplating the future of the vast territory of Oregon which was at that time firmly under the influence of Great Britain. The joint occupancy agreements of 1818 and 1827 had been little more than a gentlemanly arrangement as far as the doctor supposed. Though both England and the United States had experienced the heat of competition over the land in question, the great control wielded by the Hudson's Bay Company gave the former a decided edge. Having seen little to challenge their position in the Oregon Territory, it was natural for the doctor to assume that it would remain forever English. Fueling his sense of impregnability, the Great Plains of the American interior had served as a formidable barrier to all but the most stalwart of explorers and trappers from the East. By itself, this massive tract of rolling prairie was like an oceanic barrier which held the young and growing nation at bay. Alone, this obstacle seemed to be enough to discourage encroachment, but beyond it stood the Rocky Mountains, which waited to complete the destruction of any emigrants who might be fortunate enough to reach them. Like the majestic walls of an eternal fortress, the snow-capped peaks divided a continent and stood as sentinels, whose silent challenge could 
be sensed a hundred miles away. "It can never be reached by families but by water around Cape Horn," added the doctor with confidence.

"Before we die," countered his guest, perhaps more aware of the driving forces which had given rise to the new nation in the East, "we will see the Yankees coming across the mountains with their teams and families."

"As well they might undertake to go to the moon," was the doctor's reply. To him the matter was closed and further debate was pointless.

This conversation was related by the Rev. I. D. Driver, who had known both men personally. It was related in an address to the Pioneer Association at Pendleton, Oregon in 1887. "Years after the conversation," he went on to say, "when news of the first emigrants reached the doctor, he treated it as a joke." After the first train camped on the west side of the Cascades, however, he went out to converse with them. He "saw the dilapidated wagons, torn covers, jaded animals and sun-burned women and children, and when meeting Parrish on his return, said: 'God forgive me Parrish, but the Yankees are here, and the first thing you know they will yoke up their oxen and drive to the mouth of the Columbia and come out at Japan.!"'1

As one who had earned his place in history for his gifts of leadership, organization, far-sightedness and wise understanding of human nature, both individually and collectively, John McLoughlin had missed the mark completely. Not only had he overestimated the impregnability of his domain,

${ }^{1}$ Cited in S.A. Clarke, Vol. I, 213. 
but he had grossly underestimated the will and stamina of those who would cross both plains and mountains on what would soon be called the Oregon Trail.

Whether his miscalculations were due to his own wishful thinking, or to his naive estimation of Americans, who even then were laying the foundation of a new national character, it is an indication of his own character that he was able to recalculate his summations and adopt a policy which would allow for this unwelcome, yet inevitable flow of immigration. Little could he have imagined, however, the great role he himself would soon play in assisting the successful settlement of the very land he had regarded with such security. Not only would he give aid and refreshment when they came destitute and fainting to the gates of his fort, but he would also subsidize many out of his own pocket, in their bid to successfully settle the Willamette Valley and surrounding regions. This he would do of his own philanthropic nature, in spite of the fact that it was his patriotic and professional duty to discourage all but the interests of Great Britain and the HBC in that same land. Thus, in the pursuit of such a policy, he risked and eventually incurred the displeasure of, not only his employers, but also many who sat in positions of authority within the British government. Though well did he realize the threat the Yankees would pose to the commercial dominance that his nation had enjoyed for more than twenty years, he could not have foreseen the impact they would have on his own life and future in what he called the "finest portion of North 
America."

With little exception, visitors to Fort Vancouver were received by its chief factor, with the utmost of courtesy and hospitality. As illustrated in the case of Jedediah Smith, it made no difference as to what country they came from or whether or not they came as competitors in the fur trade. What made a difference to John McLoughlin, was the make of the man who came through his gate. If he proved to be honest, forthright and willing to work his way through life, those were all the credentials needed to win a chair at the doctor's table. If, on the other hand, he was found lacking in integrity, he could only expect a cold reception, which was calculated to encourage him to move on as soon as possible. The most obvious example of that type was found in the person of the "ne'er-do-well Englishman, Ashworth, alleged to be the son of a prominent lawyer, who had been living from hand to mouth among the American trappers until the missionaries came through, and who then came on with them to the coast." ${ }^{13}$ Upon learning that the man had come west preying solely on the good graces of each party he had encountered, "which to say the least of is discreditable," wrote the doctor in a letter to London in November of 1834, he immediately formed a course of action that left no doubt as to his sentiments:

When I found this out and that he had introduced himself into

\footnotetext{
${ }^{2}$ McLoughlin, "Autobiographical Sketch," 224.

${ }^{3}$ Rich, $\underline{\mathrm{HBC}}, 660$.
} 
the Room I had given the missionaries and taken his lodgings with them (which I did not know till the evening when I sent for the missionaries to supper) and had followed them into our house, I allowed him take his supper at our table on account of the missionaries with whom he had obtruded himself, but as he was withdrawing and seeing that he was inclined to make himself at home, I told him that this house was not an Hotel and desired the servant to open the Doors of the Fort and let this Gentleman go out. As we could not allow him starve along side of the Fort I have given him the same rations as to our own men, salmon and biscuit or potatoes and salmon as it occurred. I do not know what he intends to do but I am told he is desirous of going to Woahoo, and to get rid of him I will give him a passage to that place and which I mention that, in case he is what he states, and complains of not being better treated, your honors may know what I have done. ${ }^{4}$

Two of the most noteworthy examples of visitors to the Oregon country who received equally chilly receptions are found in the well documented cases of Hall J. Kelley and Ewing Young. A brief mention here is necessary due to the fact that the repercussions from them were felt long afterwards and may well have played a part in the sad climate of events that surrounded the closing years of the doctor's life. Also it was Kelley who had gained some influence in the States prior to his arrival at Vancouver by his campaign to stir up interest and thus win governmental support for establishing an American settlement in Oregon.

Kelley was a school teacher and surveyor by trade. He was also the

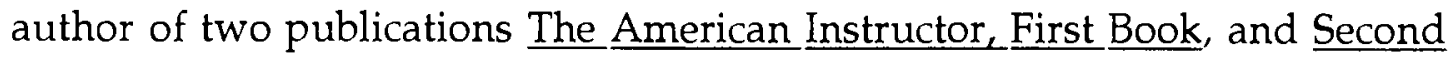
Book, which had become both popular and profitable. Thus, in spite of the

\footnotetext{
${ }^{4}$ Rich, Letters, vol. I, 126-127.
} 
fact that he had lost his job with the Boston schools, the royalties had made him a man of property. Added to the fortunate circumstances in which he found himself, was an inner fire of ambition that burned within him and kindled the desire to do something with his life that would make a difference. It was the reading of Nicholas Biddle's journals of Lewis and Clark, however, that fed that desire and gave him a direction to follow, and a worthy goal to pursue. It was here that he caught the first vision of carving an American settlement in Oregon. "In the year 1817," he claimed, "the word came expressly to me, to go and labor in the field of philanthropic enterprise and promote the propagation of Christianity in the dark and cruel places about the shores of the Pacific."

After the joint occupancy agreement of 1818 , the scheme quickly began to materialize in his mind as to how an established settlement in the region would serve a multiple function. Not only would it bring civilization and religion to the Indians, but the economic prospect also seemed excellent, due to the fact that "the Northwest Coast was a convenient and profitable stopping point on the way to the Orient." ${ }^{16}$ The plan, however, was slow in unfolding, and winning the support of the United States Government was proving to be difficult. In 1827, following the indefinite extension of the joint occupancy

${ }^{5}$ Fred Wilbur Powell, $\underline{\text { Hall }}$ I. Kelley on Oregon, (Princeton: Princeton University Press, 1932), ix.

${ }^{6}$ Ibid. 
agreement, Kelley made his first bid for national support by traveling to Washington and submitting a "Memorial of citizens of the United States, praying for a grant of land, and the aid of Government in forming a colony on the Northwest Coast of the United States." 7 Though it was received favorably by many congressmen, no action was taken. A similar bill was submitted on the 5 th of January, 1831 by Thomas H. Benton, with similar results. ${ }^{8}$

Not dissuaded, Kelley used his ample energies and resources trying to promote his dream, and by June of 1831 he had won enough favor with the Massachusetts legislature, that he was allowed to campaign publicly through the means of newspapers, lectures and the circulation of pamphlets. This freedom, he exercised to the full extent of his abilities, and though meeting with only marginal success, an expedition to the Northwest was planned for the following spring. Exactly how much effect Kelley's actions had on arousing interest in the Oregon country may never be known, but at least one of the initial subscribers of the expedition was to crop up again in Oregon history. That was Nathaniel J. Wyeth. ${ }^{9}$ As he came to know Kelley better, however, his confidence in the man and his scheme began to wane and he struck out on his own to seek his fortune in Oregon.

Kelley's long awaited journey westward was an ordeal that nearly cost him

7Powell, p. x, Full document entitled "Settlement on the Oregon River", (20 Cong. I sess., H. doc. 139), 4.

${ }^{8}$ Ibid., xi.

${ }^{9}$ Ibid.,92. 
his life. He was robbed and left by members of his expedition in New Orleans and was forced to abandon much of his property before sailing for Mexico. By the time he arrived in San Diego on April 14, 1834, he was accompanied only by a single native guide. It was there that he first met Ewing Young and persuaded the doubtful trader to accompany him on to Oregon. ${ }^{10}$ Moving northward through California, the company was joined by what proved to be, a band of "marauders," who had stolen horses in the local settlements. Kelley contracted malaria in the Sacramento Valley and while convalescing at Monterey he encountered Michel La Framboise, one of John McLoughlin's trusted employees. It was largely through the ministrations of the chief trader that Kelley was revived enough to travel, and on the 27th of October, 1834, he was presented to Chief Factor McLoughlin at Fort Vancouver. His string of unfortunate luck was not over, however, for preceding his arrival, a letter from Governor Figueroa of California had arrived, naming both Kelley and Young as horse thieves. McLoughlin, thus prejudiced by the correspondence, would only see to Kelley's immediate physical needs, and would not admit him to mingle with the society of the fort, nor to have business dealings with anyone in the vicinity. Settlers in the Willamette were given notice to have nothing to do with Young, who arrived a few days later. In short, they were to be treated as outcasts.

If being branded as a horse thief was not bad enough, what must have

${ }^{10}$ Powell, Kelley, xv. 
added to the sting was the fact that other visitors at the fort were receiving a very different kind of treatment. Newly arrived from the east was Nathaniel Wyeth and several other Americans, who were afforded all the blessings of hospitality and fellowship the fort had to offer. Though they were countrymen with whom Kelley was acquainted, they too, had been prejudiced by the correspondence, and generally ignored him or treated him with contempt. Kelley's own comments concerning the unfortunate matter reveal the jaundiced view he took of his treatment at the hands of the "Good Doctor" of Fort Vancouver and indicate that he felt much of it was due to the discovery that his errand was one of promoting settlement:

In Oregon at the time of my arrival at Vancouver, I was suffering bodily debility, for which the best available remedy would have been nourishing food, and moderate and habitual exercise in the open air. Nevertheless, I was thrust into the Company's hospital. I consented, though unwillingly, and was kept there while a sufficient opportunity was afforded to overhaul my baggage, and examine its contents. In a trunk made of a wild bull's hide, were deeds, charts, historical accounts, and other papers, showing myself to be in possession of the evidences of a good title in the Americans to the fairest portions of the island just named; and also, showing myself to be the attorney and advocate of the claimants. After the discoveries in the baggage, measures were immediately taken by the chief factor of the company, to prevent intercourse and concert of action between me and my settlers; believing, as undoubtedly he did, that to put Kelley out of the way would render it less difficult to break up the settlement, and to retard emigration; and to perpetuate the Company's hold upon the lands belonging to the Americans. Wherefore I was represented as an imposter, and as slandering the settlers, who, becoming incensed against me, threatened, by letter and otherwise, to take my life. The orders, then, were--treat him, and destroy the nucleus of the settlement. Martyrdom seemed inevitable. The orders, afterwards, in this country, were--treat him at all times, and in all places with insult and abuse; follow 
him hard up with calumny and outrage; and break him down, mind and body,--utterly destroy him. ${ }^{11}$

McLoughlin, on the other hand, makes little comment in his November 18,

1834 report to London of either Kelley or Young, except to say:

As a proof that it is necessary for us to be cautious how we act with those persons who cast up here: on the 17th Octr. I had accounts that a Mr. Young and fourteen men were arrived in the Willamette with a large band of horses from San Francisco, and by the Lama I received a letter from the Governor of upper Calefornia, copy of which accompanys this, informing me that a Joachim Young had stolen two hundred horses from the inhabitants of that settlement. Mr. Kelly of Boston who was endeavouring to form a colonization society among his Countrymen to settle in the Willamette arrived here with Young, he is in our Hospital sick of the fever and he says that the horse thieves overtook the rest of the party after they left San Francisco. ${ }^{12}$

In recounting the incident years later McLoughlin recalled:

Young maintained he stole no horses, but admitted the others had. I told him that might be the case, but as the charge was made I could have no dealings with him till he cleared it up. But he maintained to his countrymen and they believed it, that as he was a leader among them, I acted as I did from a desire to oppose American interests. I treated all of the party in the same manner as Young, except Kelley, who was very sick. Out of humanity I placed him in a house, attended on him and had his victuals sent him at every meal till he left in 1836, when I gave him a passage to Oahoo. ${ }^{13}$

From Hawaii, Kelley returned to the States where he continued to promote the cause of settlement in the Willamette. Thoroughly incensed at the

"Powell, Kelley, 145.

${ }^{12}$ Rich, Letters, First Series, 127-128.

13"A Narrative by Dr. McLoughlin", Oregon Historical Society Quarterly, vol. 1,(March 1900), 195. 
treatment he had received at the hands of McLoughlin, he also enthusiastically engaged in vilifying him and the company he represented. Not only did he attack them with unrelenting zeal, but to them he ascribed nearly every woe that befell him in his efforts to pursue his dream :

The Company had in its employment, west of the Rocky Mountains, for nearly thirty years, from fifteen hundred to two thousand men, whose business it was to hunt and trade with the Indians; to speak plainly, to cheat and kill Indians, and get gain. The objects of my enterprise in the same territory, was to colonize and to humanize, and to save life, as far as divinely permitted; to subdue those wild regions, and make them appear charming like unto the fair fields of Christendom. Another object, one highly offensive to the company, was to drive the heathen out from the goodly land, beyond De Fuca's Sea. The reader, therefore, will perceive a conflict of interests, a threatened ruin to the company's monopolies, and the final overthrow of its power.

Dr. John McLoughlin, the chief officer of the company in Oregon, was kept informed of my movements in the States. The persecuting monster, anticipating my coming to the place of his abode, was ready, with sword in hand, to cut me down.

Doubtless, he has continued to operate with the friends and hirelings of the company, devising cunning plans, and employing to the utmost, his prolific powers of invention, to prejudice the minds of the public men, and prevent progress in my welldoing. ${ }^{14}$

Kelley's continued attacks on the doctor eventually aroused enough concern that an investigation into the matter was ordered by President Andrew Jackson. William A. Slacum, a former purser in the American Navy, was sent to Oregon by U. S. Secretary of State John Forsythe to "obtain some specific and authentic information in regard to the inhabitants of the country in the neighbourhood of Oregon, or Columbia river; and, generally, endeavour to

${ }^{14}$ Powell, Kelley, 180-181. 
obtain all such information, political, physical, statistical and geographical as may prove useful or interesting to this government." 15

McLoughlin was not fooled by Slacum, who arrived aboard the bark Loriot, though in a letter to London written on January 17, 1837, he stated that the man had represented himself as one who had come to "meet some friends with whom he intended to cross the continent." Later to Governor Simpson, he went on to say, "As to Mr. Slacum I am of the opinion he is an agent of the American Government come to see what we are doing."16

Though aware of his true purpose for being there, McLoughlin treated the American agent with as much hospitality as any guest at the Fort. It is not unthinkable that he was even afforded a degree of preferential treatment with the intention of gaining a more favorable report. When problems arose, for instance, with Young and the handful of settlers in the Willamette, regarding the trader's desire to create a distillery and sell whiskey, the doctor apparently did what he could to delay Slacum's departure in order to have the matter cleared up agreeably while his guest was there to witness it. ${ }^{17}$ There was little that McLoughlin could do to ensure a favorable impression, however, for apparently the agent's mind was made up before he had set foot in Oregon. The real purpose of his trip was more or less to verify the opinion he already

\footnotetext{
${ }^{15}$ William A. Slacum, Oregon Historical Society Quarterly, vol. 8, (March 1918), 175-224.

${ }^{16}$ Rich, Letters, First Series, 185.

${ }^{17}$ Montgomery, 231.
} 
had. A careful look at his report reveals as much by his negative interpretation of the facts he included and the peculiar absence of those that would have painted a more positive picture. For instance, upon learning that the American settlers in the Willamette were desirous to purchase cattle, he was careful to note that it was he who had offered free passage on the Loriot, which was awaiting his departure, to anyone who wished to go to California for the purpose of procuring cattle. He also noted the hasty formation of the Willamette Cattle Company and $\$ 500$ he generously added to the $\$ 1,600$ which was accumulated from among the settlers. Thus, his report not only carried a negative impression of the affairs of the Hudson's Bay Company and its chief factor, but it also portrayed its author as a magnanimous benefactor to the patriotic cause of civilizing the far West. What he conveniently could not recall at the time he wrote his report was that John McLoughlin, on behalf of the Hudson's Bay Company, was also a generous contributor. His contributions would not only restock the company herd but assist the settlers as well. The doctor recalled the arrangement years later:

I took half the stock for the Hudson's Bay Company, so that by purchasing a larger number (as the expense of driving five hundred or a thousand was the same) as it would make the cattle cheaper.... They brought, I think, about seven hundred head in cattle, which cost $\$ 8$ per head rendered. In the Willamette, the settlers kept the tame and broken in oxen they had belonging to the Hudson's Bay Company, and gave their California wild cattle in the place, so that they found themselves stocked with tame cattle which cost them only $\$ 8$ per head... ${ }^{18}$ 
Had Slacum included this in his report, the effect would have been spoiled. Quite obviously it was the American agent's purpose to portray the Hudson's Bay Company as a heartless monopoly and the chief factor as an uncompromising tyrant. Had he included all of the details his illusion would have been destroyed.

Ewing Young, through all of this, was still chafing under the cloud of suspicion that attended him and was not silent in his distaste of the treatment received from the chief factor. He too, was instrumental in stirring up local discontent among the inhabitants of the Willamette Valley. So strongly did he declare his innocence that Dr. McLoughlin was moved to write Governor Figueroa for affirmation of the charge. Young also wrote to the governor asking why he had been accused of such underhanded dealings. Eventually McLoughlin received a response from Figueroa in which he admitted that an error had been made and that Young and Kelley were both innocent. McLoughlin's attempts to make amends with Young were largely rebuffed and he continued to spread his negative sentiments toward the doctor and the Hudson's Bay Company among the American settlers. ${ }^{19}$

These seeds of discontent were to germinate further in the years to come and plague John McLoughlin until his death. Some even tainted the hearts of those who had reason to thank the doctor for services rendered. The Methodist mission to Oregon, for example, met with his unwavering support,

${ }^{19}$ Johnson, 134. 
through donations of money, the loaning of supplies and making boats, horses and other useful items available for their use. It was largely through their efforts, however, that his later life was one of torment. Nevertheless, throughout his service as chief factor at Fort Vancouver, his generosity to those who came to Oregon was unwavering, whether their cause was to extend the bounds of Christianity or establish the bounds of settlement.

Among the first to investigate the religious prospects in the region was the Reverend Jonathan S. Green, who came from the Hawaiian mission which had been established by the American Board of Commissioners for Foreign Missions in 1820. He arrived on the Pacific Coast in February of 1829 aboard the bark $\underline{\text { Volunteer }}$ and after examining the various local tribes, made his recommendation that a mission be established among those in the Columbia River country. No action was taken..$^{20}$

The interest in bringing religion to the Indians was not all one-sided. As early as 1824 , on his initial visit to Fort George, Governor Simpson had received requests from Indian chiefs to send them a missionary through which they could be taught the spiritual ways of the white man. He promised to look into the matter and in his journal he made the following observations regarding the matter:

I do not know of any part of North America where Natives could be civilized and instructed in morality and Religion at such a moderate expense, and with so much facility as on the Banks of

${ }^{20}$ Johnson, 105-106. 
the Columbia river. . . . I have spoken to several of the Chiefs \& principal men on the subject of forming Establishments on their Lands for Religious purposes, and they have assured me that nothing could afford them so much delight as having Spiritual instructors among them. ${ }^{21}$

It was some years before the company acted upon the request and in the mean time American missionary efforts began in earnest. Nothing stirred them into action with such zeal and excitement as the appearance in St. Louis, in 1831 , of four Indians who allegedly came seeking the book that the white men had in their possession which contained directions on how to worship the Great Spirit. The "flathead" letter written shortly thereafter by William Walker, white chief of the Wyandot tribe and himself a Methodist was cause for much excitement among missionary-minded religionists. According to Loewenburg, the letter marked "the starting point of American entry into the Oregon country."22 Of the first to be inspired by such news was Hall J. Kelley, who at that time was just beginning to formulate his dream of colonizing the Pacific Northwest. Coming as a second witness to Biddle's Lewis and Clark publication, it seemed to be a call from heaven which he made the cornerstone of his message..$^{23}$

Among the first to hear that call were Jason Lee and his nephew Daniel

${ }^{21}$ Merk, Fur Trade, 106.

${ }^{22}$ Robert J. Loewenberg, Equality on the Oregon Frontier, Jason Lee and the Methodist Mission, 1834-1843, (Seattle and London: University of Washington Press, 1976), 8.

${ }^{23}$ Clarke, 291. 
Lee of the Methodist Episcopal Church. Within four months they were commissioned to go to the Flathead country west of the Rocky Mountains and establish a mission. They soon met Nathaniel Wyeth, who had already traveled west, and made arrangements to accompany him on his next expedition. After passing through the Flathead country and weighing the prospects of a mission among the mountain tribes, they changed their minds and pushed on toward the Willamette Valley. Rev. Gustavus Hines, himself a missionary in Oregon some years later, explained:

They (the Lees) ascertained, on their journey down from Fort Hall, that the Flat Head tribe of Indians was not only very small, but very disadvantageously situated for the establishment and support of missionary operations among them; and this brought them to the determination to proceed down to the lower country, to find a more eligible site for the location of the mission. ${ }^{24}$

John McLoughlin, also played no small part in their decision to locate in the Willamette:

In 1834 Messrs. Jason and Daniel Lee, and Messrs. Walker and P. L. Edwards came with Mr. Wyeth to establish a mission in the Flathead country. I observed to them that it was too dangerous for them to establish a mission; that to do good to the Indians they must establish themselves where they could collect them around them; teach them first to cultivate the ground and live more comfortably than they do by hunting, and as they do this teach them religion; that the Willamette afforded them a fine field; that they ought to go there and they would get the same assistance as the settlers. They followed my advice and went to

${ }^{24}$ Gustavus Hines, Missionary Expedition to Oregon, (New York: Arno Press, 1973, c1850), 11. 
the Willamette. ${ }^{25}$

According to Clarke, "Governor McLoughlin always reproached himself

that his company and British missions neglected the evangelizing of the

natives." ${ }^{16}$ To the Lees and future missionaries, thus, he offered the full hand of

fellowship and assistance. In his diary entry for September 16, Lee described

his reception at the fort and the encouragement received from his new host.

Arrived at Vancouver at 3 o'clock, found the governor and other gentlemen connected with the fort on shore awaiting our arrival, and conducted us to the fort and gave us food, which was very acceptable, as we had eaten our last for breakfast. We received every attention from these gentlemen. Our baggage was brought and put into a spacious room without consulting us and the room assigned to our use, and we had the pleasure of sleeping again within the walls of a house after a long and fatiguing journey, replete with mercies, deprivations, toil and prosperity. The dinner was as good and served in as good style as in any gentleman's house in the east. Dr. McLoughlin, the governor of the fort, seems pleased that missions have come to the country and freely offers any assistance that it is in his power to render. It is his decided opinion that we should commence somewhere in this vicinity. O Lord, do thou direct us in the choice of a location. ${ }^{27}$

In opening the fort to the missionaries, McLoughlin was not being blissfully benign. As sympathetic as he was to their religious endeavors there were other reasons for his generosity. After all, these were Americans and if

${ }^{25}$ John McLoughlin letter, quoted in Theresa Gay, Life and Letters of Mrs. Jason Lee, ( Portland: Metropolitan Press, c1936),16. Also quoted in H. K. Hines, Missionary History of the Pacific Northwest, (Chicago: The Lewis Publishing Company, 1893), 91.

${ }^{26}$ Clarke, 289.

${ }^{27}$ Jason Lee, "Journal", Oregon Historical Society Quarterly Vol. 17, (March 1916), 262. 
they were the vanguard of others to follow, it would be well to have them settle below the Columbia where, it was assumed, the ultimate line between the two nations would be drawn. He was also influenced somewhat by his assistant, James Douglas, who suspected that the missions could not avoid, either directly or indirectly, "entering into the trade and that it would cause the company more trouble than an active commercial competitor." Any attempt on the part of the Company to compete with them might cause them to raise the cry of "persecution" to their government. "It would be hopeless to try and undersell the mission," he further reasoned, "since it would have no overhead costs for keeping up establishments." It was his strong recommendation, therefore, that, "if possible, an arrangement might be made by which the Company should supply the mission's needs at moderate prices and so keep it from trading." 28

Surely these considerations helped the doctor balance his generosity with his commitment to remain a "good Hudson's Bay Man." Ultimately, according to Rich, he shared Governor Simpson's view that the missionaries and other settlers posed no serious threat to the fur trade..$^{29}$ Loewenberg, however, indicates that it was Simpson's belief that any United States citizen in the region was there at the instigation of the American government and therefore must be viewed as an "aggresive effort to push the British out of Oregon

\footnotetext{
${ }^{28}$ Rich, $\underline{\mathrm{HBC}}, 677$.

${ }^{29}$ Ibid., 660.
} 
altogether." ${ }^{130}$ The governor felt that such problems with the U.S. could be avoided if a definite boundary line were drawn. ${ }^{31}$ His reasoning was not without substance. Thomas $\mathrm{H}$. Benton's decidedly anti-British posture in the U.S. Senate was one of halting the activities of British subjects anywhere within the territories and that joint occupancy in the Columbia be terminated. It was his assertion in 1829 that the 49 th parallel was already the boundary line and any claim by the British to lands southward "was very nearly aggression." 32

McLoughlin, not being disposed toward international politics, wanted only to excel at his job of operating the Columbia district. Clearly, he found himself in an increasingly delicate situation made all the worse by Simpson's withholding information regarding company policies that, according to Loewenberg, would have helped him "cope with the difficulties of his position", and would likely have prevented those surrounding the land claim at the Willamette Falls. ${ }^{33}$ In any event, the doctor forged on following his conscience and supplied the missionaries with new horses in exchange for the ones they had left at Walla Walla, and loaned them seven oxen, eight cows with calves, and a bull. Thus, by October 6, 1834, the Methodist mission,

\footnotetext{
${ }^{30}$ Loewenberg, 29-30.

${ }^{31}$ Ibid.

${ }^{32}$ Tbid.

${ }^{33}$ Ibid., 34.
} 
though indebted to the Hudson's Bay Company, in specie, and to the chief factor, in benevolence, began its work under favorable circumstances. ${ }^{34}$

His treatment of Wyeth, whose reasons for coming to Oregon were purely and openly commercial, reveal another side of the chief factor. Despite the fact that their respective interests placed the two gentlemen somewhat at variance with each other, a warm friendship developed between them. Two excerpts from Wyeth's journal indicate his summation of both the doctor and the overall atmosphere created by his influence. The first was recorded upon his initial arrival, while the second was made after his departure.

Arrived at the fort of Vancouver...Here I was received with the utmost kindness and hospitality by Dr. McLoughlin, the acting Governor of the place. Our people were supplied with food and shelter....I find Dr. McLoughlin a fine old gentleman, truly philanthropic in his ideas. The gentlemen of this company do much credit to their country by their education, deportment, and talents....The Company seems disposed to render me all the assistance they can. ${ }^{35}$

I parted with feelings of sorrow from the gentlemen of Fort Vancouver. Their unremitting kindness to me while there, much endeared them to me, more so than would seem possible during so short a time. Dr. McLoughlin, the Governor of the place, is a man distinguished as much for his kindness and humanity as for his good sense and information; and to whom I am so much indebted as that he will never be forgotten by me. ${ }^{36}$

McLoughlin's own observations regarding Wyeth are perhaps as revealing

${ }^{34}$ Johnson, 110.

${ }^{35}$ Frederick G. Young, ed., "Correspondence and Journals of Nathaniel Jarvis Wyeth, 1831-1836", Sources of the History of Oregon, vol. I, parts 3-6, (Eugene: University Press, 1899),143.

${ }^{36}$ Ibid. 147. 
of himself as of his friend. Not only do we see the basis for a mutual appreciation between the two, but we are also afforded a glimpse of the criteria employed by the doctor in character assessment. How the doctor may have responded toward Wyeth, had the Yankee been able to successfully challenge the $\mathrm{HBC}$, however, is open to speculation.

In justice to Mr. Wyeth I have great pleasure to be able to state that as a rival in trade, I found him open, manly, frank, and fair. And, in short, in all his contracts, a perfect gentleman and an honest man, doing all he could to support morality and encouraging industry in the settlement. ${ }^{37}$

By 1835 , the Columbia was drawing more interest from religious sources. In that year the American Board of Commissioners for Foreign Missions sent reinforcements in the person of Samuel Parker, who wintered at Fort Vancouver and received the usual hospitable treatment at the hands of his host. Extending his generosity toward the cause of Christianity, in the late winter of the following year, Dr. McLoughlin sent a donation of $\$ 130$ to the Methodist missionary settlement in the Willamette with the accompanying note:

FORT VANCOUVER, 1st March, 1836.

The Rev. Jason Lee,

Dear Sir:

I do myself the pleasure to hand you the enclosed subscription, which the gentlemen who have signed it request you will do them the favor to accept for the use of the Mission; and they pray our Heavenly Father, without whose assistance we can do

${ }^{37}$ Clarke, 219-220. 
nothing, that of his infinite mercy he will vouchsafe to bless and prosper your pious endeavors, and believe me to be, with esteem and regard, your sincere well-wisher and humble servant.

$$
\text { John McLoughlin }{ }^{38}
$$

In the fall of the same year on the twelfth of September another party of missionaries made their appearance at the fort. Though they were little more than the next small seeds of settlement, no one could deny their significance. When the canoe in which they were passengers landed at shore, out stepped Dr. Marcus Whitman accompanied by his wife, Narcissa, and the Reverend Henry Harmon Spalding with his wife Eliza. Also in the company was William Henry Gray. The Americans were not only crossing the mountains with increasing regularity, but they were bringing their women with them.

The bustle of civilized life must have seemed a great contrast to the travelers after their months in the wilderness. Seeing two of the company's six ships moored at the pier "dressed in complete regalia from stem to stern" and the "sound of hammars, click of the anvils, the rumble of carts, with tinkling of bells", together with the exotic mix of people and languages, caused Narcissa Whitman to refer to the fort as the "New York of the Pacific Ocean." ${ }^{139}$ Considerably weakened by the effects of the journey, the women remained at the fort for the next two months while their husbands explored the country

${ }^{38} \mathrm{G}$. Hines, 76.

${ }^{39}$ Julie Roy Jeffrey, Converting the West, A Biography of Narcissa Whitman, (Norman and London: University of Oklahoma Press, 1991), 92. 
seeking a suitable location to establish their mission. "By not ignoring the halfcaste wives and children of the establishment, Mrs Whitman brought a new and pleasing element into the social life of the post, singing an hour every evening with the children and teaching them new tunes, including the familiar hymn 'Watchman, Tell us the Night."'40

While passing down the Columbia, Dr. Whitman had thought that the Dalles presented an optimum site to build their mission, but he was dissuaded by McLoughlin, who warned him that the Indians of that vicinity were a dangerous lot. He suggested locations farther up stream where the Indians were preferable and he offered to supply workmen, provided that they would not receive wages higher than those paid by the HBC. Waiilatpu, near Fort Walla Walla was selected by Whitman, while Spalding chose Lapwai, near the present city of Lewiston, Idaho. In a letter to her mother, dated December 5, 1836, Narcissa described the assistance they had received from their "Excellent friend and kind benefactor, Doctor John McLoughlin," who had also arranged their travel back up the treacherous river to begin building the new missions with their husbands:

We left Vancouver, Thursday noon November 23 in two boats...We were well provided for in everything we could wish. good (sic) boats, with strong and faithful men to manage them. Indeed eight of them are Iroquois Indians from Montreal, men accustomed to the water from their childhood \& well acquainted

${ }^{40}$ Johnson, 111-112. 
with the dangers of the river. ${ }^{41}$

As has been seen, McLoughlin commonly advised missionaries where he believed their efforts would bear the greatest fruits. In this his motives were multiple., he, nonetheless, did so with the best of their mutual interests at heart. H. K. Hines, himself a missionary to Oregon commented on the sincerity of McLoughlin's advice and assistance:

Some writers have believed, or affected to believe, that the advice of Dr. McLoughlin both to Mr. Lee in 1834 and to the missionaries of the American Board in 1836, was for the purpose of pushing them to the side, and putting them out of the way of the Hudson's Bay Company, so that they could not interfere with its purposes, nor put any obstacle in the way of the ultimate British occupancy of Oregon. Such writers give little credit to the astuteness of Dr. McLoughlin, or to the intelligence and independence of the missionaries of the American Board. Had such been the purpose of Dr. McLoughlin, or had he been a man capable of devising a course of action so adverse to the purposes for which his guests were in the country, he certainly would not have advised them to establish their work in the very centers of the great region open to their choice. This he did, we believe, honestly and honorably. ${ }^{42}$

Part of the policy regarding American immigration was, nevertheless, designed to point them south of the Columbia River. McLoughlin had been advised as early as 1824 that the Company's directors assumed that the river would be the most probable boundary line which would eventually separate American and British territories. As yet, the American settlers, however, were

\footnotetext{
${ }^{41}$ Narcissa Whitman, "Letters 1836-1839", Oregon Historical Society, \# 1203.

${ }^{42} \mathrm{H}$. K. Hines, Missionary History of the Pacific Northwest, (Chicago: The Lewis Publishing Company, 1893), 452-453.
} 
so few and unobjectionable, that his tolerance of them had caused little concern to Simpson or the directors in London. "But the feeling, that McLoughlin might be less entirely devoted to the company than was proper was spreading."43

In 1838 the doctor made the journey to London to discuss plans to establish a British colony in the Puget Sound region, hence strengthen British claim to lands north of the river. The meeting neither substantiated nor allayed their fears. The doctor, himself, was beginning to have concerns about the future of his empire. Developements in the territory among the Methodist missionaries had not missed his eye. By the spring of 1838 the Methodist leaders were facing the fact that their mission was failing. Jason Lee, hoping to encourage more support from the Methodist Board and believing that the Willamette was well adapted to settlement by Americans, conceived the idea of establishing an American colony under the protecting arm of the United States Government. A memorial was drafted and signed by every male in the mission, Ewing Young, sixteen Americans and nine French-Canadians. It was carried to the eastern states by Lee, himself, who remained several months drumming up interest in his enterprise. The result of his efforts was that in October of 1839, a party of preachers, farmers, physicians, mechanics and school teachers sailed from New York aboard the Lausanne, bound for the Columbia River. It arrived at Fort Vancouver on June 1, 1840. The "Great

${ }^{43}$ Rich, $\underline{\text { HBC }}, 662$. 
Reinforcement" consisted of 36 adults and 16 children. ${ }^{44}$ This, added to the organization of the Willamette Cattle Company, the growing feelings of nationalism, and of forming a local government, which had been kindled by Slacum, and the "covetous glances he had cast upon the Puget Sound country-all...conspired to disquiet the mind of the doctor."45

When McLoughlin returned from the London conference in 1839, he focused his attention northward toward enlarging the market that had been established among the Russians and toward developing the resources available in the Puget Sound region. Whatever his private thoughts may have been, he received the newcomers with the same courtesy and respect shown to their predecessors. It was not long before he became convinced that the religious nature of the mission was being supplanted by its role as a foundation for stirring further political interest in Oregon in the United States. ${ }^{46}$

In October of 1839 the remnants of a party of travelers calling themselves the "Oregon Dragoons"17 began arriving at the fort singly and in pairs. Their leader was Thomas J. Farnham, who had led the group from Peoria, Illinois, with the intention of taking possession of the land in the Columbia and establishing an American settlement. In desperate need of clothing, he was

\footnotetext{
${ }^{44}$ Johnson, 151.

${ }^{45}$ Montgomery, 235.

${ }^{46}$ Ibid., 237.

${ }^{47}$ Johnson, 152.
} 
outfitted by the chief factor and invited to stay through the winter. Instead he spent his time among the American settlers stirring them sufficiently to encourage their petition to Congress for the extension of governmental protection. The document which reached Congress on June 4, 1840 gave the impression that the settlers were at the mercy of savages and other unsavory elements intent on doing them harm and called for federal protection. Adding to the anti-British, anti-Hudson's Bay Company sentiment of the petition was the decidedly anti-papist contribution of Lee and his fellow Methodists who viewed the Catholic presence as a major threat to their own missionary efforts. The petition reached Congress and was soon followed by a similar one sent by Captain Spaulding, pilot of the Lausanne. Though there was little to substantiate the accusations, a new era was dawning that cast a shadow of concern in the United States regarding the Pacific Northwest.

In 1841, the doctor's spirits were boosted by the arrival of Lieutenant Charles Wilkes, who had been sent on an exploring expedition by the United States government. Differing in his attitude and mission from Slacum, he and Dr. McLoughlin warmed to each other from the start. The fort was open to his party and he was given a thorough tour of the region. His keen eye was quick to discern also that the missionaries seemed "more occupied with the settlement of the country and in agricultural pursuits than in missionary labors. Whereas Slacum had proclaimed that Oregon was already American territory, Wilkes advised the American settlers not to press their point until the 
boundary question had been arranged." ${ }^{48}$ His advice convinced them to abandon attempts to form a local government for the present time. Regardless of how they felt toward the control exercised by John McLoughlin and the Hudson's Bay Company, he reminded them, they had little to complain about. "The officers of the Hon. Company have not only quieted the country," he wrote in his diary, "but their operations have been so admirably conducted that they have opened the country to safe emigration and rendered the task an easy one to its peaceful possession." ${ }^{49}$ It becomes apparent that with the fruits of his success in management of company affairs in the Columbia region, the doctor was inadvertently planting the seeds for its ultimate withdrawal.

Though the assistance extended by Mcloughlin had been well appreciated, he was, nevertheless, becoming increasingly unpopular among the settlers. The members of the Methodist mission invariably spoke highly of him but they felt pinched by his absolute rule over the country. One of the reasons for their discontent was the fact that the $\mathrm{HBC}$, because of its determination to keep the fur trade in their own hands, would not buy beaver skins from them. Lt. Wilkes was not sympathetic to the mission in this regard either. It was his contention that a missionary who embarked on the path of economic gain destroyed his usefulness by diverting his attention from the religious cause he

${ }^{48}$ Rich, $\underline{\mathrm{HBC}}, 700$.

${ }^{49} \mathrm{Charles}$ Wilkes, Lieutenant, USN, Diary of Wilkes in the Northwest, Washington Historical Society Quarterly, Vol. 16, 299. 
was engaged in. If the missionaries found him less of an ally than they had hoped for, his estimation of them had become equally unfavorable. Upon his departure from the fort in June of 1841 he noted the following:

On the morning of the 17th the Fort was in a stir at an early hour. About 10 o'clock we were all summoned by Dr.

McLoughlin to the Hall to take a parting cup....All were present Missionaries and all the household. The former ought to have stayed away for if they had been at my funeral instead of leave taking they could not have been so repugnant to good fellowship $\&$ feeling. ${ }^{50}$

It would be another two years before the settlers' desire for local government would be realized. By that time, immigration from the states in significant numbers had begun and the chief factor of Fort Vancouver found himself in the uncomfortable position of pitting his in-bred sense of loyalty to company and country, at odds with his innate sense of humanity, which made it virtually impossible to turn the outstretched hand of the needy away from his gate. His reconciliation to the latter, even at the expense of his own best interest remains one of the most poignant chapters of American history, and surely one that breaks the mold of either the stereotypical frontiersman, mentioned in chapter one of this work, or of the all-too-familiar image of the cold, power-hungry, business czars who have cluttered our history from its inception to the present. While it is true that the doctor ran a class-conscious establishment at Fort Vancouver, in which officers and common laborers received vastly different treatment and accomodations, he was, nontheless,

\footnotetext{
50Wilkes, 64.
} 
considered my many to be one who responded to the needs of his fellow creature with a remarkable degree of equality. T.C. Elliott acknowledges that "he loved to be on common ground with the people. Nothing revealed this more than his treatment of the common immigrant. ${ }^{.51}$

The first overland immigration of significant numbers arrived in the Columbia region in the fall of 1842 . They consisted of a party of approximately one hundred Americans led by Dr. Elijah P. White, who had been empowered by Secretary of War, John C. Spencer, to manage, as a subagent, all Indian affairs west of the Rocky Mountains. Though most of them remained for only one season before pressing on to questionably greener pastures in California, the Oregon Trail had become a reality that signalled the dawn of a new era in settlement for the inhabitants of Fort Vancouver as well as for those who populated the great expanding nation in the East.

McLoughlin treated them with his customary good will. "In the Summer a number of the immigrants of last year," he wrote, "headed by Mr. Hastings, not being satisfied with the Country, left for California. As they were destitute of means, I made them advances which they were to pay to the late Mr. Rae, at San Francisco, but few did so."52

In May of 1843, the Americans gathered at Champoeg and voted in favor

${ }^{51}$ T. C. Elliot, "Guests", 65-66.

${ }^{52}$ John McLoughlin, "Narrative", Oregon Historical Society Quarterly, vol. I, 199. 
of framing a local government. McLoughlin and the Company officers, knowing that it had no actual power and aware that the population of Americans was still outbalanced by Canadians, ignored it. The balance soon changed, however, for in the fall came nearly a thousand immigrants into the region. They "drove their cattle over the Cascades by the same route as those of last year to the Willamette," wrote the doctor. "Yet with the assistance I lent them, they still suffered a great deal, and the last parted Vancouver only at Christmas." 53

Typical of his treatment of the immigrants was that extended to William Beagle, who arrived at the fort with his family, sick with typhus. McLoughlin sent fort physician, Dr. Barclay, to fix a house for them and attend to their needs. For two months the entire family was cared for until Beagle recovered. When he approached the chief factor and asked how much his bill was, he was told, "Tut, tut, tut! Bill, bill, bill!" Beagle, apparently an honorable man, not given to accepting free service, protested. "Tut, tut, tut. You do the best you can for some other man who is in trouble and that will pay me,"54 came the reply! He saw to it that the man and his family were transported up the Willamette River and charged them nothing. Beagle later repaid Dr. McLoughlin in full.

It did not take a gift of foresight to see that the drain on HBC supplies

\footnotetext{
53McLoughlin, "Narrative", 199.

${ }^{54}$ McLoughlin, "Autobiography", Clarke, 228.
} 
from the first two years of immigration would lead to trouble. If a sufficient amount of seed was not sown in 1843 and 1844 , clearly there would be a famine in 1845 . This, he anticipated, would lead to violence against the fort. "To avert this," he reminisced years later, "I freely supplied the immigrants of 1843 and 1844 with the necessary articles to open farms, and by these means avoided the evils. In short, I afforded every assistance to the immigrants so long as they required it, and by management I kept peace in the country, and in some cases had to put up with a great deal." ${ }^{15}$ In 1844, "to maintain peace and order," he obtained permission from Governor Simpson to join with the American immigrants and form a temporary local government, empowered with the authority to enact and enforce laws.

It was not only necessary, but absolutely our duty, as in 1843 , seeing the large number of immigrants that season, and seeing from the public papers it was expected the numbers would be greater next year, and as they came from parts of the United States most hostile in feeling to British interests which was greatly excited by the perusal of Irving's Astoria. Kelly and Spalding's letters, several copies of which were among them, in which our conduct and proceedings were represented in the blackest and falsest colors, had worked so much on the minds of these immigrants that I found out that they frequently talked among themselves that they ought to take Vancouver. They now know these reports were false, but as prejudice takes a strong hold of people's minds, and of which others might avail themselves to form a power to make an attack on the Hudson's Bay Company that it was necessary to get protection from the government for the security of HBC's property, and to which in June 1845 I received their answer stating that in the present state of affairs the company could not obtain protection from the government, and that I must protect it the best way I could...I am

${ }^{55}$ McLoughlin, "Autobiography", Clarke, 228. 
certain there are many ill-disposed persons among the immigrants who think they are doing a meritorious act by giving trouble to British subjects. ${ }^{56}$

Though precautions were taken to protect $\mathrm{HBC}$ interests, and in spite of the alarm now openly voiced by company directors in London over the generosity shown to the American settlers, McLoughlin did not waver in his determination to lend assistance when and where he deemed it was needed. "When we reached Vancouver," wrote W. W. Walker in his journal of reminiscences, "Dr. McLoughlin of the Hudson's Bay Company gave us food, the first time we had enough to eat for weeks. Many (became) sick from over eating...but none died...The first thing we did after obtaining food was trade our two poor oxen for one fat one for beef, we also got some wheat with potatoes, so that winter we ate boiled wheat with potatoes and meat." ${ }^{157}$

Hugh Cosgrove, arriving too late in the year to secure land and shelter, was provided a "small house with a big fire place." He spent that season "happy as a king to be under a roof once more." From the home in the fort, he left his family "in safety", to search for an adequate homestead.$^{58}$ Another arrival of 1845 was Sarah Hill who mentioned in her journal the following transaction made at the fort in an effort to trade their sick livestock for healthy ones of the company's that were on Sauvie Island:

${ }^{56}$ McLoughlin, "Narrative", 200-201, 203, 206.

${ }^{57}$ W.W.Walter, "Reminiscences of a 45'er", Oregon Historical Society, \# 739.

${ }^{58}$ Hugh Cosgrove, "Reminiscences of Hugh Cosgrove", Oregon Historical Society Quarterly, vol. 8, (March 1900), 253. 
It rained all day. I had a linsey skirt around my shoulders as a wrap. I did not have a dry thread on me. we (sic) landed here November 10 and presented our papers to Dr. McLaughlin. when he examined them said tut tut gentlemen this will never do! the cattle on the island are wild and you can never do anything with them. You give me $\$ 2.50$ per head and I will take care of them then in the spring you go up and get your cattle, so we got ours. At Vancouver we got all the Butter, Salt, Beef and provisions we wanted. ${ }^{59}$

According to Rich, "the sheer numbers of the immigrants greatly affected, and divided, the Hudson's Bay officers who were nearest at hand. Following the great immigration of 1843 came a further 1,400 in 1844 and then almost 3,000 in 1845."60 The doctor disregarded his instructions from the directors and continued to supply them. "By 1844 he had lent goods and seed to the amount of over six thousand pounds upon very little security." His argument was that he feared the starving immigrants would sack the fort. He sought protection from the British government, but "little could be got from government, and although a small sloop, the Modeste, did indeed pay a visit to the Columbia in 1844 , her officers did little to enhance British prestige and nothing to arouse a feeling of loyalty." 61

To compound the troubles that the doctor seemed unable to avoid, the Company property at the Falls on the Willamette had become a subject of heated debate. Having made the claim in 1828 following instructions from

\footnotetext{
${ }^{59}$ Sarah Hill, "Letters of Sarah Hill", Oregon Historical Society, \#1508.

${ }^{60}$ Rich, $\underline{\mathrm{HBC}}, 717$.

${ }^{61}$ Ibid.
} 
Govenor Simpson, by the 1840 's, when American interests had become stronger south of the Columbia, McLoughlin found himself fighting to retain it from the Methodists, who desired it for themselves and regarded the Hudson's Bay Company as illegal owners. Assuming that the land would soon be under the jurisdicition of the United States the Americans regarded any claim south of the Columbia by British subjects as worthless. To counter this position, while visiting the area in 1841, George Simpson ordered Company officials to reenforce their hold on the site, take possession of water privileges, and install a sawmill to "compete with the American interlopers." It was also at this time that McLouglin directed the lay out of Oregon City by J. M. Hudspeath, a recent immigrant. ${ }^{62}$ To counter the efforts of the Methodists, who had encouraged Felix Hathaway, a mission employee, to build a house on the island which the doctor considered "part of his claim; McLoughlin built a house there as well."63 As he did so he began to strengthen his own private interests in the area.

Strengthening the resolve of the settlers was the news brought in by Elijah White and Lansford Hastings in November 1842 which affirmed that a land bill submitted by Lewis Linn was before the Senate which would grant 640 acres to each U.S. settler. Already in effect was a law passed on September 4, 1841 called the Distribution-Preemption Law, which favored the preemptor

\footnotetext{
${ }^{62}$ Sampson, xxxvii.

${ }^{63}$ Ibid.
} 
and made cultivation and residence legal prior to purchase. ${ }^{64}$ Though Oregon was not part of the public lands, the common national belief held that it soon would be. Added to the strength of such beliefs was the fact that on July 5 , 1843, "the newly organized Provisional Government of Oregon, which was dominated by the Methodists, passed a Law of the Land Claims which excluded McLoughlin from the Oregon City site." Though it became illegal for the doctor or any other individual to claim water privileges on city or townsites, the law conveniently stipulated "that any mission which held such claims previous to the law was exempt" from such limitations..$^{65}$ On these grounds the Methodists held firm and bolstered their position by contending that McLoughlin's claim was illegal, not only because of his absenteeism, but because they were the first permanent settlers at the falls. The Shortess petition of March 25, 1843, which formalized the controversy was, according to Loewenberg, "a transparent bid for American protection by the Island Milling Company" owned and operated by the Methodists and was designed to break McLoughlin's power in the region. ${ }^{66}$ By the following year the doctor was finding the battle at the falls to be a personal one as Company officials began to shift their focus northward.

"The obstacles placed before McLoughlin continued to grow," writes

$$
\begin{aligned}
& { }^{64} \text { Loewenberg, } 189 . \\
& { }^{65} \text { Sampson, xxxviii. } \\
& { }^{66} \text { Loewenberg, } 204 .
\end{aligned}
$$


Sampson, "for in December, John Ricord, an attorney acting for (the Reverend A. F.) Waller, wrote a proclamation to the people of Oregon stating that McLoughlin had made no formal claim to the land until two and a half years after Waller had moved to the Falls, that McLoughlin had never resided on the land he claimed, and that the Hudson's Bay Company, not McLoughlin, was the claimant in fact." In order to hold on to any property in the region the doctor was thus forced to "deny in writing that the claim belonged to the Company. ${ }^{167}$ Hoping to secure the land claim, he entered into a settlement with Waller and David Leslie, acting superintendent of the mission holdings at the falls. He paid Waller five hundred dollars and gave him an additional eight lots and three blocks in Oregon City. He also gave the mission itself an additional six lots and one full block. In April of 1844 the Reverend George Gary, Lee's replacement, offered to sell them back to the doctor as the failed mission was disposing of its property. The proposed sum was six thousand dollars. ${ }^{68}$ Though incensed at such tactics, the doctor finally agreed to pay the amount in hopes that his troubles had ended. The entanglement of legal affairs that ensued is beyond the scope of this work, but is referred to merely to illustrate the various fronts upon which the energies and resources of the doctor were being taxed. Not only was he finding it increasingly necessary to defend his immigrant policy to company officials, his position as representative

\footnotetext{
${ }^{67}$ Sampson, xxxviii.

${ }^{68}$ Montgomery, 302.
} 
of the $\mathrm{HBC}$ was making him increasingly unpopular among the settlers. The legal battle, by 1844 , had become a fight to maintain possession of his personal property which he had hoped would see him through retirement. One can only imagine the state of mind that accompanied his midnight hours and greeted him with each sunrise. In a letter to his friend Nathaniel Wyeth written in 1847 , it is obvious that he as yet had received little rest, but expressed a hope for an end to the "dreadful troubles" and "Immense Evils" that still plagued him in Oregon City. ${ }^{69}$

His troubles with immigrants were not confined to the region south of the Columbia. In 1844, the first encroachment of Americans north of the river was made by Henry W. Williamson and Marvin Alderman. Not more than two miles from the fort they erected a log cabin and posted a notice that they intended to claim the land as their own. Though the doctor was able to convince the men to withdraw, the last wall of his carefully guarded domain had been breached and it was only a matter of time before more settlers would seek to exploit the opening. In July of 1845 , Michael T. Simmons took seven families into the Puget Sound region to claim lands at Tumwater. The doctor, perhaps growing weary of the fight and by now sensing the inevitable flow of civilization, gave Simmons "a letter of introduction to the commander of Fort Nisqually, whom he instructed to supply the settlers with grain and potatoes,

${ }^{69}$ Sampson, 21-22. 
which were to be charged against Vancouver." ${ }^{170}$ That same summer he further incurred the wrath of his superiors by accepting an invitation from Jesse Applegate, whom he regarded highly, to join the provisional government. One of the desires of the men involved was to create a county north of the Columbia in order to protect Americans living there. Hoping to avoid a confrontation with the Hudson's Bay Company, Applegate suggested that McLoughlin assume the management of the new county, which in turn could only be accomplished with him as a member of the provisional government. ${ }^{71}$ McLoughlin's decision to accept the invitation nearly coincided with the arrival in 1845 of two British army officers; Henry J. Warre and Mervin Vavasour, who were "selected by the commander of the British forces in Canada, in consultation with Sir George Simpson, to conduct a confidential military reconaissance of the area between Sault Sainte Marie and the Pacific Ocean. ${ }^{172}$ McLoughlin himself was kept in ignorance of their mission while they remained at Fort Vancouver from August, 1845 through March of 1846. The still undefined boundary was causing tensions between the two nations concerned. Though diplomats in Washington had been lax in pressing for a settlement, the rising clamor of American settlers was causing the question to become a national concern. With the election of James K. Polk's to the White

\footnotetext{
${ }^{70}$ Johnson, 222.

${ }^{71}$ Ibid.

${ }^{72}$ Sampson, 6n.
} 
House in 1845, "the climate in Washington for an Oregon settlement became even less favorable," writes Merk. Polk was committed by his campaign slogan of "fifty-four-forty-or-fight" and by a campaign promise, to a program which would not allow Britain or any foreign power to maintain an interest over any portion of either Texas or Oregon. ${ }^{73}$ The first bill to organize a territorial government was presented to Congress in February of 1845. Though it did not pass the Senate, the message was clear to Britain that matters could deteriorate rapidly. Many American settlers were threatening to cross the Columbia and seize HBC lands. The Company called for naval support and increased its fortifications. "Here were all the ingredients of a borders' clash," writes Merk. "Were one to occur, it was likely to echo through the excitable Middle West," with the possibility of igniting an "explosion into war in the charged atmosphere of Anglo-American relations. ${ }^{74}$

It was in this spirit that Warre and Vavasour were sent into the Columbia. Their report brought additional problems. It was highly critical of the doctor's handling of affairs in regards to American immigration. When its contents were made public in London, the following year, immediate criticism was focused on the chief factor. Those in high office believed that, whereas the Hudson's Bay Company was doing all in its power to validate British claim to

${ }^{73}$ Frederick Merk, The Oregon Question, Essays in Anglo-American Diplomacy and Politics, (Cambridge: The Belknap Press of Harvard University Press, 1967), 218.

${ }^{74}$ Ibid., 219. 
the lands north of the Columbia, the chief officer on the spot was doing everything in his power to assist the opposition. It was even charged that at heart, McLoughlin was an American citizen. ${ }^{75}$ The doctor resented the fact that the two officers had acted as spies without his knowledge and felt that they should have made use of the information that he could have provided them. "Above all," states Sampson, "he resented the fact that they had not given him an opportunithy to explain his actions before they submitted their report to London." ${ }^{176}$ The following excerpt from their report indicates the nature of their assessment of McLoughlin's immigrant policy:

In conclusion we must beg to be allowed to observe with an unbiased opinion, that whatever may have been the Orders or motives of the Gentlemen in charge of the Hudsons Bay Company's posts, their policy has tended to the introduction of the American Settlers into the Country. We are convinced that without their assistance, not thirty families would ever have been in the settlement. The first Immigration in 1841 or 1842, arrived in so miserable a condition, that had it not been for the trading posts of the Hudsons Bay Company, they must have starved or been cut off by the Indians.

Through motives of humanity, we are willing to believe, and from the anticipation of obtaining their Exports of Wheat and flour to the Russian Settlements and to the Sandwich Islands, at a cheaper rate, the Agents of the H.B. Co. gave encouragement to their settlement, and Goods were forwarded to the Wallamette Falls, and retailed to these Citizens of the United States, at even a more advantageous rate than to British Subjects. Thus encouraged, Emigrants left the States 1843, 1844 \& 1845 and were received in the same cordial manner, their numbers have increased so rapidly, that the British party are now in the minority and the Gentlemen of the Hudsons Bay Company have

\footnotetext{
${ }^{75}$ Johnson 233.

${ }^{76}$ Sampson, 8n.
} 
been obliged to join the Organization without any reserve except the mere form of the oath of Office, their Lands are invaded, themselves insulted, and they now require the protection of the British Government against the very people to the introduction of whom they have been more than accessary. ${ }^{77}$

An exhaustive letter from McLoughlin was sent to London in which he addressed and refuted nearly every line of the above report. In answering their charge that he sold goods at a cheaper rate to the Americans than to British subjects, for example, he wrote the following:

I am afraid the credit these Gentlemen give me for humane motives will avail me but little. As no goods were ever sent by the Hudson's Bay Company or any one connected with them to be retailed to these Citizens of the Untied States at a cheaper rate than to british Subjects, and as they failed to ascertain a fact so easy to be ascertained and so simple as this It may be supposed by the World that they have been equally unfortunate in ascertaining the springs of that complex piece of machinery the human breast. Mr. Chief Trader Ermatinger who had the management of the Store at the Falls till he left to go to Red River with Messsrs. Warre and Vavasour could have informed Sir George Simpson on this point. ${ }^{78}$

"I am happy they have been able to ascertain my motives for assisting the Immigrants," he stated with no sign of the strain under which he must have labored, "though they have not been quite so fortunate in discovering my reasons for giving encouragement to their Settlement..." ${ }^{179}$ Despite his extensive and spirited defense, his efforts were of little impact. Almost overshadowing 286-287.

${ }^{77}$ Report included in Appendix to Rich, McLoughlin Letters, Third Series,

${ }^{78}$ Ibid., 287.

${ }^{79}$ Ibid., 289. 
the issue concerning the doctor's policy regarding the Americans was his attack on Sir George Simpson for his method of handling the unfortunate circumstances surrounding the murder of John McLoughlin, Jr. at Fort Stikine. The two issues combined as further witness to Whitehall that the doctor was becoming a hindrance they could ill-afford to keep. From that point on it was only a matter of time before the severance of his relationship with his company and country was complete. In view of events that will be dliscussed in the following chapter regarding the circumstances surrounding the death of McLoughlin's son and the subsequent fued with George Simpson, it is likely that the Committee was, at this time, building a case for the doctor's dismissal. In any event, he was not to go without a fight. Years later, after his leaving the service, he still passionately and publicly defended his position. One can detect the weariness in his tone and the toll the years of stressful leadership had taken on him when he penned the following statement shortly before his death on the 3rd of September, 1857:

By British demagogues I have been represented as a traitor. For what? Because I acted as a Christian, saved American citizens, men, women and children from the Indian tomahawk and enabled them to make farms to support families. American demagogues have been base enough to assert that I had caused American citizens to be massacred by hundreds of savages. I, who saved all I could. I have been represented by the delegate from Oregon, S. R. Thurston, as doing all I could to prevent the settling of Oregon, while it was well known to every American settler who is acquainted with the history of the territory that is a downright falsehood. Most certainly he will say that he most firmly believes that I did all I could to promote its settlement, and that I could not have done more for the settlers if they had been my brothers and sisters, and after being the first to take a 
claim in the country and assisting the immigrants as I have, my claim is reserved after having expended all the means I had to improve it, while every other settler in the country gets his. But, as I have felt convinced that any disturbance between us might lead to a war between Great Britain and the United States, I felt it my bounden duty as a Christian to act as I did, and which I think averted the evil, and which was so displeasing to some English demagogues that they represented me to the British government as a person so partial to American interests as to sell the Hudson's Bay company goods in my charge cheaper to Americans than I did to British subjects. Yet, after acting as I have, spending my means and doing my utmost to settle the country, my claim is reserved while every other settler in the country gets his, and how much this has injured me, is daily injuring me it is needless to say, and, certainly, it is a treatment I do not deserve and which I did not expect. to be brief, I founded this settlement and prevented a war between Great Britain and the United States, and for doing this peacefully and quietly I was treated by the British in such a manner, that from self respect, I resigned my situation in the Hudson's Bay company's service by which I sacrificed $\$ 12,000$ per annum, and the Oregon land bill shows the treatment I received from Americans. ${ }^{80}$

Still seeking vindication, he later described his position in more thoughtful, though no less passionate terms. Perhaps by then he was more resigned to his lot and sought only to balance the scales of history with greater accuracy than he had experienced with those of justice:

I early foresaw that the march of civilization and progress of peopling the American territory was westward and onward and that but a few years would pass away before the whole valuable country between the Rocky Mountains and the Pacific, then used only as hunting and trapping grounds and as the resting place of native tribes, must become the abode of another race--American. This could be neither successfully resisted, nor did I deem it politic or desirable to attempt it. In this spirit I prepared myself to encourage, hasten, and further what I thought would be not only attended with good, but inevitable. The absence of a cold, 
and chilling policy calculated to check and embarrass immigration to Oregon, has subjected me in Europe to strictures as untrue as they have been unjust, but this I cannot wonder at or complain of, for it is the province of selfishness and conservatism. to frown upon and discourage all liberal ideas and efforts from whatsoever source they may proceed. Such things do not, therefore, annoy me, and, if I can truly feel that in my day and generation I have done something, however slight, to advance the cause of civilization, freedom, and true progress, I am abundantly repaid all the injury which the illiberal and unjust, in other lands may have heretofore cast upon me, or may hereafter find in their hearts with which to blacken my name and character. ${ }^{81}$

Having lost most of his wealth in the legal battles with the Methodist mission, the doctor retired to the remaining property he owned in Oregon City where he consumed much of his dwindling time and health attempting to settle accounts with those who had yet failed to repay his past expressions of generosity. Besides legal expenses, he had purchased some of the land twice; initially from the $\mathrm{HBC}$, then selling under pressure to the Methodists and buying it back as they liquidated their assets upon closure of the mission. His once held dream of an "uninterrupted possession" of the land "for our children", and "for all coming time", must have seemed then as little more than a whimsical flight of youthful fantasy. Spurned by those of his native land, and relatively unappreciated by those of his adopted country, he had charted his course by the dictates of his conscience. The great role he had played in facilitating the successful and peaceful growth of civilization was of little comfort to him in his waning years. It would be left for later generations to

\footnotetext{
${ }^{81}$ McLoughlin, "Narrative", 296.
} 
better appreciate the full impact his influence had on the successful settlement of the Oregon country. 


\section{CHAPTER III}

\section{McLOUGHLIN AND FELLOW LABORERS IN THE FUR TRADE}

When John McLoughlin left his practice of medicine to pursue an active career in the fur trade, he made a decision that would have far more of an impact on the lives of more people than any success he may have enjoyed as a private physician. The threshold of his surgery was for the "Good Doctor" his own Rubicon, and though crossing it for the last time as a practicing physician would not land him a throne on the banks of the Tiber, it would, eventually, win him one on the banks of the Columbia, and also a significant chapter in the history of two nations. His motive for doing so, however, was more the product of an ambitious desire to improve his station in life than of a lust for power and the right to rule.

From the days of his formal training, it appears clear that his strong will and assertive nature were the type of qualities which, for him, held the promise of success. Those same characteristics in a lesser man may have propelled the holder to ample achievements, but in John McLoughlin, they were the compelling ingredients that forced his other attributes to the surface, creating a character that only needed the right opportunity to make a mark in history. Power seekers such as Julius Caesar or Napoleon Bonaparte, were men whose patience apparently wore thin in awaiting such circumstances of fate. After weighing the odds of success, such men forged ahead to create for themselves what Providence had, thus far, failed to present them. 
McLoughlin, on the other hand, waited, sometimes impatiently, for the open door and then stepped confidently through it when it arrived. Indeed, a close study of his life might lead one to conclude that opportunity sought for him rather than vice versa.

Exactly what motivated young McLoughlin to engage in the study of medicine, remains a mystery. Likewise, his motive for seeking the fur trade to further his ambitions is equally unclear. Speculation stemming from contact with his uncles; Simon Fraser, who served as a doctor in the British army, and Alexander Fraser, who was a chief trader for the North West Company, is somewhat uncomfirmable. The fact that both individuals were rarely, if ever, present during those early years of the boy's life leads Burt Barker to conclude that "it is more probable that Dr. John McLoughlin was influenced to follow in their footsteps by the mere fact that he knew of their work and, boylike, admired them."1 It was apparent, however, that his grandfather, Malcom Fraser, whose influence on the boy was substantial, encouraged him to follow a career in which he could remain a gentleman. ${ }^{2}$ Dorothy Morrison and Jean Morrison, however, offer another possibility. They base their conjecture on two letters found in Barker's The McLoughlin Empire and its Rulers, Family Letters of the McLoughlins, on pages 147 and 165 respectively. The first is

'Burt Brown Barker, The McLoughlin Empire and its Rulers, (Glendale: A. H. Clark Company, 1959), 33.

${ }^{2}$ Montgomery, 14. 
dated July 1, 1808, in which McLoughlin tells his uncle, Simon: "I cannot accuse no one but myself of my bad fortune as it was entirely by my own conduct that I came up to this Country ... I would much rather have gone to the West Indies as you propos'd." The second is dated July 28th 1814. In it, the young McLoughlin states: "People talk of the dessert of Siberia, but this is as bad the only difference is that the people are sent and kept in it by force here they come by choice for my part I am sorry I ever came to it however this was perhaps not a matter of Choice but of Necessity on my part." ${ }^{.3}$ is their assertion that the young McLoughlin may never have wanted to enter the fur trade in the first place, but only did so out of necessity. They further offer the possibility of the young man's fleeing to the North Woods because of troubles he had gotten himself into in one of the major cities of eastern Canada, and cite a story related to Eva Emery Dye in 1893 by McLoughlin's nephew, Henri DeChesne. The story involves the young McLoughlin on a muddy street in a major Canadian city. There was, apparently, an altercation with a rude English army officer and a female friend of the doctor, which ended with the officer lying in the mud. The Morrisons cite as additional evidence, a letter by Herbert Beaver, arch-enemy of John McLoughlin, written to the editor of the Church of England Protestant Magazine, March 1841, and reprinted in the Oregon Historical Society Quarterly, volume XXXIX, March 1938, page 32:

\footnotetext{
${ }^{3}$ Dorothy Morrison and Jean Morrison, "John McLoughlin: Reluctant Fur Trader", Oregon Historical Society Quarterly, Vol. LXXXI, No. 4, (Winter, 1980), 379.
} 
"Besides, it had been reported, and confirmed, that our foe [McLoughlin] some years previously, had been compelled to quit Montreal, under circumstances I will not trust myself to avert to."4

In any event, before entering the fur trade, the young McLoughlin was sufficiently inspired to pursue the study of medicine at the age of fourteen. He served four and a half years as an apprentice to Dr. James Fisher, a prominent Canadian physician of the day. Our first glimpse of this portion of his life comes from a petition, dated April 1803, in which the aspiring nineteen year old requested permission to leave his studies and practice medicine. His graceful and flowing penmanship reveals a controlled, sensitive hand, apparently considered as a trivial asset by physicians of a later day. The spare, efficient nature of the correspondence, however, is in marked contrast to his later writings, which are often ponderous, rambling and wanting in adequate punctuation.

"This will certify that John McLoughlin a Canadian," begins the endorsement he received from Dr. Fisher, in a noticeably less appealing hand, "served with me as an apprentice student in Medicine, Surgery \& Pharmacy for four years and six months - during which time, he behaved honestly, he possesses talents, and I sincerely believe him a good subject to the British Government."

\footnotetext{
${ }^{4}$ Morrison, 383.

${ }^{5}$ Barker, Empire, Appendix II, plate11.
} 
Though Montgomery indicates that he may have practiced for a short time in Montreal, ${ }^{6}$ his employment with the North West Company had to have occurred almost immediately after the end of his apprenticeship with Dr. Fisher. It was through the instrumentality of his uncle, Dr. Simon Fraser, who at this time had resigned his commission with the army and was engaged in private practice, that the young doctor was hired in 1803 , the same year he left his studies with Dr. Fisher. His first assignment was at company headquarters at Fort Kaministikwia, later renamed Fort William, on the north shore of Lake Superior. There he replaced and assumed the duties of Dr. Henry Munro.? Serving as the resident doctor, however, required him to travel throughout the region and spend substantial time at other forts. We know, for instance, that he spent time at Fort Duncan, north of Fort William on Lake Nipigon, and later that same year he wintered at nearby Sturgeon Lake. It was there that he struck up a friendship with Daniel Williams Harmon a recently appointed partner in the company. ${ }^{8}$

McLoughlin worked five years in that capacity, without finding much satisfaction. The reason for his discontent was not so much a distaste for the type of work as it was for the amount of his salary. In a letter to his uncle, written on the first of July, 1808, he acknowledged that he had "been doing Dr.

\footnotetext{
${ }^{6}$ Montgomery, 20.

${ }^{7}$ Barker, Empire, 147.

${ }^{8}$ Montgomery, 20.
} 
Munros duty these past five years" but had not been receiving appropriate pay. ${ }^{9}$ Part of his frustration was due to the fact that because his contract had been negotiated through his uncle, his status was not that of an original company apprentice and thus, had not been put into writing. Consequently it was subject to interpretation, and any concerns that he harbored had to be directed through his uncle. ${ }^{10}$ It was a peculiar arrangement, but it would be several years before matters would improve.

The doctor's indignation at what he felt was an inferior salary caused him, eventually, to weigh carefully the advantages of further employment with the company. Tempted to quit altogether and make his own way, he even considered taking over his Uncle Simon's practice in the event that he should rejoin the British army. ${ }^{11}$ There was another reason, however, that the young doctor was concerned about his pay. His brother, David, who was studying medicine in Edinburgh, was desperately lacking the funds to continue. John felt obligated to help. "There is one thought that unmans my fortitude," he wrote on the 13th of July, 1808, "and that is the fear that my brother David should [not] finish his education through want of means. It was and is still (if I should remain) my intention to help him as much as possible, indeed to be

\footnotetext{
${ }^{9}$ Barker, Empire, 147.

${ }^{10}$ Ibid., 36.

"Ibid., 35 .
} 
answerable for what necessary amount he should require."12

Of passing interest is the fact that during this period of his employment, he received an offer to go to the Columbia. He mentions it only causually in a letter to Dr. Fraser in 1812 and instead of offering further details, he merely goes on to express his concern over the current war between Britain and the United States and the effect it was having on Canada. ${ }^{13}$ It is likely that he turned the offer down because he was not a full partner at that time, and thus the position held no promise for advancement.

When young McLoughlin's apprenticeship ended, he was in the position to bargain for a higher salary. The company offered to pay him an annual fee of 150 pounds. In response, he told Chief Director William McGillivary, that he would leave the company if he did not get 200 pounds. In a letter dated July 16,1812 , he reported to his uncle Simon, that he had accepted "two hundred a Year." ${ }^{14}$ Not only were his bargaining skills becoming apparent, but the other ones he possessed must have been obvious enough to warrant the approval of his superiors. A year later, those same skills had borne enough fruit for him to announce in his annual letter to Dr. Fraser, that he had "the promise of becoming a partner of the N W Co on the Outfit of the Year 1814." ${ }^{15}$ The long

\footnotetext{
${ }^{12}$ Barker, Empire, 149.

${ }^{13}$ Ibid., 159.

${ }^{14}$ Ibid.

${ }^{15}$ Ibid., 160.
} 
awaited door of opportunity had not only arrived, but it stood invitingly open. There is no indication, as he stepped through it, and effectively turned his back on the field of medicine, that he felt any pangs of regret, or ever looked back. A promising and lucrative career in the fur trade lay before him, which would allow him to assist his brother David and progress satisfactorily in pursuing his own ambitions.

Upon learning of his father's death, which occurred on the 28th of April, 1813, John McLoughlin, waxing nostalgic, expressed momentary desires to return to the life of a farmer. "It has always been my wish if I had wherewith (to buy a farm)" he wrote to his uncle in 1814, "and settle in the Country certainly a country [life] is the happiest life in the world."16 Perhaps fueling such sentiments even more, was the unpleasant rivalry between the North West Company and the Hudson's Bay Company that had evolved into a bloody dispute and threatened to erupt into a full-scale civil war. The Seven Oaks affair, mentioned previously, in which Governor Robert Semple and twenty of his twenty-seven attendants were killed, had not involved the doctor personally, but as a partner in the company, he was held as an accessory after the fact. It will be remembered that he had voluntarily yielded himself into custody and neglected to flee when ample opportunity had presented itself. The physical and emotional stress of the trial, which subsequently ended in his acquittal, were pale in comparison to the near drowning he suffered while

${ }^{16}$ Barker, Empire, 165. 
making the crossing to York Factory. The effects of the latter resulted in an illness "that worried him for years."17

It was at Fort William that Dr. McLoughlin first met James Douglas, a young man, fresh from Scotland, who had recently joined the ranks of the North West Company. He was sixteen when he arrived at the fort on August $6,1819 .{ }^{18}$ Perhaps remembering his early days in the company, the doctor befriended Douglas and began to teach him the fur trade. It was the beginning of a professional relationship that would extend through the years ahead until McLoughlin's departure from the trade in 1846.

As a full partner, Dr. McLoughlin had, by 1820, distinguished himself sufficiently to warrant being sent to London with Angus Bethune to assist in the settlement of hostilities between the warring companies, as ordered by Parliament. Though making little, if any contribution to the negotiations, his status as a senior officer put him in line to receive the appointment of chief factor as new positions were created to fill those left by retiring employees. The doctor was taken ill upon his arrival back at Fort William in the fall of 1821 , and thus was given no immediate assignment. ${ }^{19}$

The main task at hand was to soothe the tempers and bridge the gap that naturally existed between those who once saw each other only as enemies.

\footnotetext{
${ }^{17}$ Barker, Empire, n41.

${ }^{18}$ Montgomery, 38.

${ }^{19}$ Rich, $\underline{\mathrm{HBC}}, 412$.
} 
Eventually McLoughlin was able to regain his strength enough to assist George Simpson, the newly appointed Governor, to patch together the new coalition, which retained the name of the older of the two companies. The healing of rifts was a slow process, yet the doctor labored enthusiastically and effectively to bring it about. Through the remainder of 1821 and into the early part of 1822 , he visited many posts as an ambassador and by fall the reorganized Hudson's Bay Company was again ready for business. In the spring of the year conditions had improved sufficiently for McLoughlin to assume command of Fort Francis on the Lake of the Woods. ${ }^{20}$

The next two years were relatively uneventful. In July of 1824, however, John McLoughlin was reassigned to the Columbia region and sent to Fort George to replace chief factor Alexander Kennedy. It was an assignment that was going to test his mettle to the fullest and we can only surmise that he approached it with an amount of enthusiasm equal to that which he had exhibited in past assignments. His first impressions of Oregon, however, as noted in his annual letter to Uncle Simon, dated March 15, 1825, were unfavorable. The interminable, drizzly, gray skies of that first winter were not to his liking. "I cannot say that I admire much this Country," he wrote, "The Climate is very mild but moist and cloudy to a degree indeed since my Arrival on the 6th Novr we have not seen one clear sun Shineing day and not ten days

\footnotetext{
${ }^{20}$ Montgomery, 56.
} 
without rain."21 It is evident from a subsequent correspondence in 1826, that he expected to be there no more than five years. ${ }^{22}$

Meeting Chief Factor McLoughlin on the journey to Fort George, was Governor George Simpson. The Pacific Northwest was the only region he had not examined personally since his appointment, and he went along as much to familiarize himself with the facilities and the lay of the land as to insure that the new chief factor got off to a good start. It was here that the first differences between the two men became apparent. There were, however, some less than amicable sentiments harbored by Governor Simpson, that began to surface before the two men ever reached the Columbia. Racing to catch the McLoughlin party, who had a three week head start, the governor betrays, in his journal, a hint of rivalry and disdain which he held for the doctor. In his entry of September 5, he wrote: "The Dr. is still Eight Days ahead of me and does not expect I can overtake him before he reaches Nez Perces on the Columbia, but in this he is mistaken as we shall assuredly be up with him if no accident happens before he can reach the Athabasca River." ${ }^{13}$ The entry of September 26, recorded after he had caught up with McLoughlin reveals a note of outright contempt:

he was such a figure as I should not like to meet in a dark night in one of the bye lanes in the neighborhood of London, dressed

\footnotetext{
${ }^{21}$ Barker, Empire, 176.

${ }^{22}$ Ibid., 179.

${ }^{23}$ Merk, Fur Trade, 4.
} 
in clothes that had once been fashionable, but now covered with a thousand patches of different colors, his beard would do honor to the chin of a Grizzly Bear, his face and hands evidently Showing that he had not lost much time at his Toilette, loaded with Arms and his own herculean dimensions forming a tout ensemble that would convey a good idea of the highway men of former days. ${ }^{24}$

It is assumed by some that the Governor's "Character Book" was compiled in a spirit of humor, but Glyndwr Williams does not indicate as much. Writing in the Summer, 1975 volume of The Beaver, he cites E.E. Rich's assessment of the book as one to "be approached with caution," but as still being valid. He acknowledges that while it began with "a cheerful and confident cynicism," it became "mean and captious." ${ }^{25}$ He further states the fact that it was meant to be strictly confidential as noted by Simpson's referring to the commissioned officers by numbers only. ${ }^{26}$ "The reader who was solely dependent on it," he continues, "would never realize that McLoughlin was even one of the dominant figures in the history of the Pacific Northwest."27

Simpson's assessment of the Columbia's slim potential for profit was equally prejudiced before his arrival. It did not take him long to learn, however, that the low productivity of trade in the region was due to the mismanagement of Alexander Kennedy. His pessimism over the region quickly

\section{${ }^{24}$ Merk, Fur Trade, 23.}

${ }^{25}$ Glyndwr Williams, "Governor George Simpson's Character Book", The Beaver, (Summer, 1975), 5.

$$
\begin{aligned}
& { }^{26} \text { Ibid., } 7 . \\
& { }^{27} \text { Ibid., } 13 .
\end{aligned}
$$


melted away as he reasoned that efficient management alone would make a marked improvement. ${ }^{28} \mathrm{He}$ and McLoughlin determined that for the future success of the operation a new location would have to be found. In this assessment they also found the basis for their first disagreement of note. The two conversed about their options at length. Diplomatically, yet with his customary assertiveness, the doctor argued against his superior's desire to relocate on the Fraser River and instead pressed for a site on the north shore of the Columbia. After an exploration of the Fraser River revealed that site to be unsatisfactory, Simpson conceded, and the site for Fort Vancouver was agreed upon.

The governor made it clear to his chief factor, before returning to the east, just how important the responsibility was with which he was being entrusted. The future success of the post on the Columbia, which was the largest of the districts, would depend upon efficient and proper leadership skills. Friendly relations with the Indians was essential and there was the hope of eventually establishing a settlement which could support schools and missions. ${ }^{29}$ There is no indication that the doctor shrank at the prospect of undertaking such a great responsibility, and indeed, from the enthusiasm he exerted in its undertaking, it seems apparent that his own expectations were as optimistic as the governor's. He divided his time equally between Fort George and Fort

\footnotetext{
${ }^{28}$ Loewenburg, 20.

${ }^{29}$ Merk, Fur Trade, xxvi,xxvii.
} 
Vancouver, which allowed him to accomplish a variety of vital and necessary tasks. Not only was he able to oversee the work in both places, but he was also able to win the confidence of the men who worked under him, and the friendship of the natives he encountered along the way. ${ }^{30}$

With the departure of George Simpson in March 1825 the doctor was solely in charge of the company's largest district. Lying before him was the formidable task of moving the post from its present site at the mouth of the Columbia to the newly chosen location eighty miles upstream. Then, as previously discussed, there was the matter of dealing with the varied tribes which inhabited the vast area of his jurisdiction. Not only was this a monumental task logistically and geographically, but likewise, it was no small affair in regards to company personnel. Among the most pressing of problems was the fact that in 1821, a decision and been made by the Council of the Northern Department, that chief traders should "obey all orders and instructions" given by a chief factor. After sensing the resentment such a policy created throughout company ranks, they softened it in 1822 to where questions of authority were answered by a "deference to the opinions of precedence or seniority." Even so, there were several instances of insubordination, and the Columbia region had been no exception. ${ }^{31}$ Thus, in addition to the task of establishing a new district headquarters and revitalizing

\footnotetext{
${ }^{30}$ Montgomery, 76.

${ }^{31}$ Rich, Letters, First Series, liii.
} 
the sluggish business, McLoughlin was going to be faced with the formidable responsibility of successfully managing its varied ranks of personnel. It will be remembered that through the years the employees at the post included "French-Canadians, Scotchmen, Orkney Islanders, Irish, Iroquois from the Canadian Indians, free trapping Americans, mountaineers and Kanakas from the Sandwich Islands." ${ }^{132}$ The prospect of successfully managing them all on a remote frontier outpost must have been daunting.

To add to the problem was the fact that as removed as the Columbia district was from the rest of the continent, it was decided that its only consistent contact would be by sea. The connection would be made directly from London by the barks Cowlitz, Columbia, and Vancouver. The schedule of these vessels was arranged so as to enable the maintenance of a year's supply of stores at the fort in case a mishap should occur. Later, for the coast trade, the company schooners Cadboro, Nereid, and Llama were employed, along with the sloop Broughton. ${ }^{33}$ Here was another area where the chief factor disagreed with his superior. He "believed that the coastal trade could best be conducted from fixed posts," writes Sampson, "for he felt that the use of vessels alone was needless extravagance." ${ }^{134}$ Though Simpson believed that the maritime trade would offset the competition posed by the American trade

\footnotetext{
${ }^{32}$ H. K. Hines, 45.

${ }^{33}$ Johnson, 64 .

${ }^{34}$ Sampson, xxxiii.
} 
vessels, McLoughlin reasoned that the expense of keeping a coastal fleet in repair would far outweight their advantage. This difference of opinion "was aggravated in March of 1836 when the new steamboat Beaver arrived at Fort Vancouver to have her engines installed." 35 The fact that the vessel could only travel a little over two hundred miles before needing more fuel, and that it took six axmen two days to cut sufficient wood to run the ship for one day proved that his doubts were valid. ${ }^{36}$ The natural dangers of coastal navigation, possibility of Indian attack and incompetency of the captains were other concerns that colored his thinking. ${ }^{37}$

Regardless of the size of the fleet and the assured schedules of arrivals, contact with the outside world would be severely limited. Thus, another of the foremost concerns facing the new chief factor was the transformation of a rude, frontier establishment into a bastion of civilization which would meet the needs of comfort as well as safety. That would require the maintenance of an atmosphere at the fort which would foster the mental well-being of his men and relieve the strain of boredom and isolation that was common on wilderness outposts. Apparently feeling the weight of his burden he remarked in a private letter to Chief Trader John McLeod in 1830 that he had "been placed in greater difficulties than any other [Chief Factor] has been since the

${ }^{35}$ Sampson, xxxiv.

${ }^{36}$ Rich, Letters, First $\underline{\text { Series, }}$ cxiv-cxv; and Duncan Finlayson to McLoughlin, 29 September 1836, ibid., 328.

${ }^{37}$ Glyndwr Williams, "The Pacific Coast", The Beaver, (Autumn 1983), 62. 
Columbia was Established." ${ }^{13}$

John Dunn, a naval apprentice, who arrived at Fort Vancouver in 1831, aboard the bark, Ganymede, provides a vivid glimpse of the results of Dr. McLoughlin's efforts. Much of the subsequent descriptions that have found their way into the many historical accounts of early Vancouver owe their detail to him. He noted the great picket-style log walls, supported by buttresses that formed a parallelogram approximately 250 yards by 150 yards. A bastion was placed at each corner and there were several cannons of various caliber placed at strategic locations throughout the compound. There were upwards of forty single-story buildings within the enclosure, which comprised offices, warehouses, workshops and a chapel that was used both for religious purposes as well as a school. There was also a pharmacy, a residence for bachelors, and dwellings for married officers and their families. Dominating the scene was the two-story residence of the chief factor, which included a dining hall and public sitting room. The chief factor's, residence, or "Big House" was of the French-Canadian cottage type, weather-boarded and painted white. Grape vines grew around the porch, which extended across the full witdh of the structure, and two sets of stairs, forming a horseshoe, led to the front door. At their base stood two 24-pound cannon, mounted on a ship's 
carriage. $^{39}$

The daily routine at the fort was indicative of the doctor's method of handling the affairs of commerce and life. If he was imprecise and rambling in his reports to London, he was anything but slovenly in his management of business at the fort. The daily routine ran unwaveringly according to the clock. Work began at $5 \mathrm{a} . \mathrm{m}$. when a large bell, mounted in front of the dining hall, was sounded. At 8 a.m. it was sounded again to announce breakfast, which lasted for an hour, as did all the meals. The scene was repeated for the noon meal, and the day officially ended at 6 p.m. with the call to dinner. The rigid social structure demanded by the chief factor called for the officers of the fort to take their meals separate from their families and dine in the great hall. The women, on the other hand, took their meals in their living quarters. ${ }^{40}$ Status among the women of the fort, who were Indian or of mixed blood, was determined by the "social and economic position of their husbands," writes Hussey. The "chief factors, chief traders, clerks, chaplains, and, at least at Fort Vancouver, the postmasters were considered gentlemen." All others were considered servants. ${ }^{41}$ Lively diversion was further provided by the presence of

\footnotetext{
${ }^{39} \mathrm{John}$ Dunn, History of the Oregon Territory and British North American Fur Trade, (London:, 1846.), cited in Montgomery, 160-161. Further descriptions accompanied by several excellent original photographs are also found in Alberta Brooks Fogdall, Royal Family of the Columbia: Dr. John McLoughlin and His Family (Portland: Binford \& Mort, 1982).

${ }^{40}$ Hussey, "Women", 289.

${ }^{41}$ Ibid., 279.
} 
a piper, dressed in his tartans, and filling the air of the dinner hour with the

skirl of a Highland pibroch. A typical dinner is described by Dunn:

The dinner is of the most substantial kind, consisting of several courses. Wine is frequently allowed; but no spiritous liquors. After grace has been said, the company break up. The most of the party retire to the public sitting room, called "Bachelors' Hall," or the smoking room; to amuse themselves as they please, either smoking, reading, or telling and listening to stories of their own, and others' curious adventures. Sometimes there is a great influx of company, consisting of the chief traders from the outposts, who arrive at the fort on business; and the commanders of vessels. These are gala times after dinner; and there is a great deal of amusement, but always kept under strict discipline, and regulated by the strictest propriety.... The voyageur and the trapper, who have traversed thousands of miles through wild and unfrequented regions; and the mariner, who has circumnavigated the globe, may be found telling; and in every way banishing dull care, till the period of their again setting out for their respective destinations arrives. ${ }^{42}$

To further illustrate the air of culture and facilities available at Vancouver,

McLoughlin biographer Robert C. Johnson makes the following observations:

The visitor at Vancouver, always found something of interest. There were books and newspapers, and in the smoking room were a museum and an armory in which were displayed all sorts of weapons and curiosities of both savage and civilized life. In the stable were saddle horses and on the river were canoes for fishing and hunting. Everything was governed by the etiquette and precision of a military post. ${ }^{43}$

Such diversions and regimentation undoubtedly went a long way in

keeping the threat of monotony at bay for visitors and most of the employees.

Sustaining a workable level of morale is encouraged by such practices even in

\footnotetext{
${ }^{42}$ Dunn, cited in Montgomery, Ibid.

${ }^{43}$ Johnson, 63.
} 
the face of difficulties which arise unexpectedly. However, the sweetness of life at Vancouver was not universally appreciated. In a letter to John McLeod, in $1831, \mathrm{~J}$. E. Harriot, serving in the company as a clerk, noted that due to many recent mishaps in the region, which undoubtedly included the tragic fever epidemic, there was "a great hole in our complement of gentlemen, and a number of recruits will be wanted." He then added that he didn't know where they would come from as there were few who had not already "tasted the sweets of the Columbia" and it would be hard to send them back once they had the "satisfaction of getting safely out of it." ${ }^{44}$

"The protests of the prejudiced and hypercritical Mr. Beaver can generally be discounted," writes Hussey, "but he was undoubtedly correct in indicating that his lodgings at Fort Vancouver were Spartan in their simplicity." ${ }^{45}$ William $H$. Gray, a visiting American missionary remarked that the parsonage was made of rough wood with bare, unplaned plank floors. Indian mats were available, but these the Beavers considered "too filthy to step upon, or to be about the house." ${ }^{146}$ Hussey states, however, that as plain as accomodations were at Vancouver, they were generally more comfortable than those found at the smaller remote posts. "Even at the firm's principle depot in North

${ }^{44}$ Washington Historical Society Quarterly, Vol. 2, 619-621.

${ }^{45}$ John A. Hussey, '"Unpretending' But Not 'Indecent', Living Quarters at Mid-19th Century Hudson's Bay Company Post", The Beaver, (Summer 1975), 12.

${ }^{46}$ Ibid. 
America, York Factory on Hudson's Bay, the clerk's quarters contained only the bare necessities."47

Among the varied responsibilities facing the doctor in managing the affairs of business at Vancouver was the matter of discipline. Though he ruled with military precision, he attempted to balance justice with mercy in judging quarrels and misunderstandings between the various employees, visitors and Indians. He had his own ideas of proper behavior, which included a stern rebuke of anyone who used profane language in his presence. Though seemingly inflexible in such matters, his disposition was generally regarded as friendly and sympathetic. The picture most commonly painted of him is of a leader who was as easily approachable by a "laborer as by a chief trader." 48 His approach to discipline showed an equally evenhanded pattern. On one occasion, for instance, when an Indian employee was found guilty of a gross offense, he was tied to a cannon and given five lashes. Not long afterwards, a white man was brought to the doctor and found guilty of the same offense. Without hesitation, the same punishment was ordered and carried out. ${ }^{49}$

Roderick Finlayson, an ambitious apprentice clerk, was put in charge of accounts at a grist mill which was located five miles up river from Vancouver. Each Saturday night he walked in to the fort with his weekly statement. On

\footnotetext{
${ }^{47}$ Hussey, "Unpretending", 13.

${ }^{48}$ Johnson, 89.

${ }^{49}$ Ibid., 74.
} 
one occasion he was delayed at the mill and arrived in a driving rain after the big gates had been closed for the night. One of the doctor's strict rules was that the gates were not to be opened to anyone after sunset without a permit. McLoughlin heard the exchange at the gate and chastised the young clerk for the infraction. Upon learning of the man's excuse, however, he softened and asked his assistant, James Douglas, to provide him with a horse. On the following Saturday, the young man, in an apparent lapse of judgement, galloped through the main gate and into the compound. "Who the devil is that daring to break the rules of the establishment by coming into the square in that fashion?" blustered the doctor. Realizing his error, the young man dismounted and stood at attention. After delivering a sound scolding, McLoughlin ordered his man's horse returned to the stables and Finlayson was forced to make the weekly journey on foot throughout the remainder of the winter..$^{50}$

As has been shown previously in this work, though the doctor was viewed as a despot by the Methodist missionaries and undoubtedly other settlers who came to settle in his jurisdiction there were not many who would agree that he was tyrannical. Obviously Ewing Young and Hall J. Kelley were some of the more notable exceptions. There were also those at Vancouver, however, who did not see eye to eye with the chief factor and did not take chastisement from him with as much meekness as had Roderick Finlayson. The result was

\footnotetext{
${ }^{50}$ Bancroft, Vol. II, 619-121.
} 
usually enough to bring out the worst of his temperament. There were disagreements between the chief factor and John Work, one of his chief traders, the most serious of which concerned the latter's failure to send documents that would have shed greater light on the Stikine affair. ${ }^{51}$ The feud between McLoughlin and Francis Heron, became well publicized. In a private letter written to J.G. McTavish in 1830, George Simpson noted that "Dr. McLoughlin \& Heron have got into a proper War \& the latter has the best of it but I have found it necessary to go to the Drs assistance \& give Heron a Dressing who is nothing more or less than an idle indolent Lawyer." ${ }^{12}$ It is not difficult to imagine how such an individual would incur the wrath of the doctor. Rich indicates that the difficulties arose because Heron had defied his orders. ${ }^{53}$ How the matter was resolved, remains a mystery.

It is believed by some biographers, that McLoughlin disliked Duncan Finlayson, the uncle of Roderick, who came to the fort in 1833. The elder Finlayson was an experienced chief factor and it was expected that he would manage the affairs of the fort when McLoughlin's furlough came due and he would likely make a trip to London. The assumption stems from a letter written by McLoughlin to Edward Ermatinger on February 1, 1835, in which he states: "You have one great satisfaction you act for yourself...While you

\footnotetext{
${ }^{51}$ Rich, Letters, Third Series, 24-25.

${ }^{52}$ Rich, Letters, First $\underline{\text { Series, }}$ xcix.

${ }^{53}$ Ibid.
} 
know in this Country you would be working for others and people who Know Nothing of the Business--have the power of deciding on the Merits of your conduct--and who would place a Runt of a fellow that knows Nothing--can do Nothing--as your Colleague--Merely because they want to reward a Creature. ${ }^{.54} \mathrm{Rich}$, on the other hand indicates that "the circumstances would apply very aptly to Chief Trader Francis Heron, with whom McLoughlin had had more than one violent quarrel. ${ }^{.55}$ The fact that Finlayson became an ardent supporter of the doctor also lends credence to the view that the "Creature" was indeed Heron.

The doctor also openly quarreled with Dr. Hamlyn, a medical officer, who refused to tend the company store when they were short handed, on the grounds that it was work for a common clerk. He eventually left the district in 1830 , though the fever epidemic made his services sorely needed. Rich, citing a letter to Simpson, quotes McLoughlin, who justified his reason for letting the doctor go as it was "no use to keep a Gentleman who says he will not work." ${ }^{56}$ The quarrel with Chief Trader John Warren Dease was more serious, though the details are almost totally obscure. In the same letter from Simpson to McTavish, mentioned earlier, the governor observed that the

\footnotetext{
${ }^{54}$ Rich, Letters, First Series, xcix. ${ }^{55}$ Tbid., ${ }^{56}$ Ibid., xcix.
} 
quarrel "went as far as it could well do without Powder \& Ball. ${ }^{157}$ The description of McLoughlin given by Simpson in his secret "Character Book" reveals an evaluation based on some of the above incidents:

No. 10 About 48 Years of Age--A very bustling active man who can go through a great deal of business but is wanting in system and regularity and has not the talent of managing the few associates and clerks under his authority: has a good deal of influence with the Indians and speaks the Soulteaux tolerably well.--Very zealous in the discharge of his public duties and a man of strict honor and integrity but a great stickler for rights \& privileges and sets himself up for a righter of wrongs. Very anxious to obtain a lead among his colleagues with whom he has not much influence owing to his ungovernable violent temper and turbulent disposition, and would be a troublesome man to the Comp'y if he had sufficient influence to form and tact to manage a party, in short, would be a Radical in any Country under any Government, and under any circumstances; and if he had not pacific people to deal with, would be eternally embroiled in "affairs of honor" on the merest trifles arising I would conceive from the irritability of his temper more than a quarrelsome disposition.--Altogether a disagreeable man to do business with as it is impossible to go with him in all things and a difference of opinion almost amounts to a declaration of hostilities, yet a good hearted man and a pleasant companion. ${ }^{58}$

Duncan Finlayson's assessment of McLoughlin, kept in a similar record of character sketches, offers an interesting comparison to the one quoted above. Had he been the subject of the doctor's disdain, and in view of the fact that the latter was not disposed to disguise his sentiments, it is unlikely that his observations would have been so positive:

No. 25 About 38 years of Age. A highly upright honorable

\footnotetext{
${ }^{57}$ Rich, Letter, First $\underline{\text { Series, }}$ xcix.

${ }^{58}$ Ibid., c.
} 
correct man of good Education and superior abilities to most of his colleagues. Has great influence with and is much liked by his Equals, inferiors and Natives: Speaks cree, understands accounts, is a good correspondent and is well qualified for the management either of a Depot or Trading Establishment. Firm cool and decisive, one of our best Legislators and most effective practical men, and his private conduct \& character are models worthy of imitation; in short, he may be ranked high among the most respectable and efficient men of his class. ${ }^{59}$

Though such divergent assessments of the doctor are not surprising, especially in view of George Simpson's veiled prejudice, it is somewhat peculiar to find that the governor's public appraisal of McLoughlin is much more in harmony with Finlayson. In his acknowledging the transformation of the Columbia district, his report to London, in August 1832, is decidedly in contrast with his private assessment:

This amendment I mainly ascribe to the great exertions indefatigable labours and unremitting attention of Chief Factor McLoughlin, who, in the face of every difficulty he has had to contend with, (and they certainly were of no ordinary character), has steadily \& uniformly followed up, with a degree of vigour \& energy which I have rarely witnessed in this or any other country, every measure and plan which had been determined on at the commencement of his administration in that quarter, and has now brought the business into such a train that, if it be followed up with system and regularity by those who may succeed him, will secure to the Honble. Company a branch of trade on the Shores of the Pacific which promises to become one of very great value and importance. ${ }^{60}$

There was at least one other individual worth mentioning, who found himself at odds with the chief factor. Aside from the well publicized conflict

\footnotetext{
${ }^{59}$ Rich, Letters, First Series, ci.

${ }^{60} \mathrm{Ibid}$., ci.
} 
that eventually transpired between McLoughlin and Simpson, there is none that has caught the attention of historians more universally than the affair with the Reverend Herbert Beaver. Without retreading well worn ground, it is sufficient to acknowledge that here is a classic example of a clash of personalities. Dissatisfied with, and, according to Rich, "totally incapable of adapting either himself or his creed to the inevitable crudities of a frontier trading post," ${ }^{161}$ Beaver's inevitable confrontation with the chief factor was merely a question of time. The spark that ignited the fire came with the clergyman's public denunciation of the marriage arrangement between the doctor and Margaret soon after his arrival at the fort. The fact that their marriage had been performed by an officer of the North West Company and not a church official caused Beaver to regard it as a state of "concubinage", and hence, no marriage at all. ${ }^{62}$ Though considering himself suitably married, the accusations of the clergyman apparently had their intended effect, for sometime between 1836 and 1838 the doctor and Margaret were quietly remarried in a ceremony performed by James Douglas, acting in his capacity as a Justice of the Peace. ${ }^{63}$ Nevertheless, the damage had already been done. If it was not the marriages that the Beavers found distasteful, it was any of a host of other complaints that were voiced almost continually. The rage that all

\footnotetext{
${ }^{61}$ Rich, Letters, First Series, ci.

${ }^{62}$ Hussey, Women, 273.

${ }^{63}$ Ibid.
} 
of this incited in the chief factor and finally found expression in the public caning of Beaver probably exposes the Achilles heel of John McLoughlin like no other incident in his life. Having dealt conservatively with warring Indians, free-loading vagrants, sullen American trappers, shrewd business adversaries, various clever and not-so-clever spies, unappreciative settlers, greedy and hypocritical missionaries, and insubordinate officers, it was the self-righteous clergyman from London who moved the Great White Eagle to violence. As strong tempered as the doctor was, no other man had been capable of rousing him to such a point of uncontrolled fury. As noted as he was for his sudden displays of temper, his quick return to normal temperament was equally typical. Aside from the public apology he offered Beaver on the following day, nothing more was said of the incident. When, in the early months of 1838 , the clergyman and his wife returned to London, it was business as usual at the fort.

It is of passing interest, however, and not surprising, that the feud was the cause of a small division among several of the officers at the fort. Siding with Beaver on a number of issues, for instance, was Francis Ermatinger, who withdrew his son Lawrence from the Vancouver school that the clergyman had been critical of. ${ }^{64}$ After Beaver left, it was discovered that the schoolmaster had taken some inappropriate liberties with some of the female students in his

${ }^{64}$ Lois Halliday MacDonald, ed., Fur Trade Letters of Francis Ermatinger, (Glendale: A. H. Clark Company, 1980), 191. 
charge. Consequently Ermatinger was eager to report to his brother Edward in a letter dated February 26, 1839:

The school master of which from discoveries that were made by Mr. Douglas, was this year flogged in the most public manner twice, yet not half severe enough for the villain. He ought to have been shot. The Dr. will burst when he hears of it, and it will give the person who went home a triumph over him. ${ }^{65}$

In the opposing camp, which comprised the majority, was James Douglas, whose own observations of Herbert Beaver are equally revealing. Near the end of an exhaustive report to the Committee, written on October 18, 1838, he adds the following, almost as an afterthought:

With the Revd. Gentleman I lived on very friendly terms until the $2 \mathrm{~d}$ of the present month, when the perusal of his report, now forwarded, induced me to seek explanations, of certain passages contained in its 20th page; and on his refusal to comply with a request to that effect, I declined holding further intercourse with him, beyond the interchange of those relative duties, which our respective situations in the service, rendered unavoidable;...

Dissatisfied, apparently, with the exclusive privilege of remaining here an idle spectator, of the busy throng around him; that Gentleman also usurps a sort of prescriptive right, to libel, by his discoloured statements the character of every person with whom he associates. Were these writings, offered only for your perusal, the evil might be bourne in silence, as our characters are too well known to be affected by flimsy misrepresentation; but when, through the medium of Mr. Beavers select men, the direful passages, designed, as they report, not to reprove vice; but to blast reputations and procure expulsion from the service, are noised about throughout the settlement, they become an insufferable nuisance and highly prejudicial to the service. ${ }^{66}$

There were other matters besides morale and discipline that reveal a view

${ }^{6}$ MacDonald, 217.

${ }^{66}$ Rich, Letter, First Series, 266-267. 
of John McLoughlin's approach to leadership. On more than one occasion it was his duty to order his men into circumstances that would place their lives in jeopardy. As has been shown in chapter I, when dealing with the native population, there were several times when punitive action was deemed necessary, and the doctor was quick to act in a manner that he felt would bring about the best outcome. In his approach to this unpleasant task, he was not insensitive and even displayed a certain reluctance in exposing his men to danger. Though the task had to be done, he would not force anyone to involuntarily put his own life in jeopardy. For instance, in the portion of his journal kept while preparing for the dangerous expedition to punish the Clallam Indians for the murder of four Hudson's Bay employees, Francis Ermatinger noted:

Friday, 13th, 1828 ...this morning affairs appeared more determined and a muster was made of all the effective men upon the ground, both free and hired, and they were told by Chief Factor McLoughlin, of the necessity of going off in search of the murderous tribe, and if possible, to make a salutary example of them, that the honour of the whites was at stake, and that if we did not succeed in the undertaking it would be dangerous to be seen by the natives any distance from the Fort hereafter. All the men assented, or rather none appeared unwilling, but Challifoux, who happened to make a remark mal a propos, and was immediately turned out of the hall and his services refused. This answered well, as it led the men to think that volunteers only were wanted and all were ashamed to keep back.

Monday, 16th ...I upon the hint we got yesterday are prepared to follow as no further notice had been given us, except, indeed, my being told to take my watch with me. In fact, $\mathrm{Mr}$.

McLoughlin appears delicate in requesting anyone to go, lest an unwillingness should be shown.

In the evening the men received a regale and the Iroquois 
went through a war dance, in character, before the Hall Door. ${ }^{67}$

When inevitable reports of death among company employees arrived, they took their toll on the man in charge. "The Dr. is troubled in mind and would, I believe, like to leave the country," observed Ermatinger in a letter to his brother in March of 1841. "By every arrival this year we have the account of some death or other. Today Mr. Douglas returned from California and brought the report of the murder of Thomas Simpson--but we have faint hopes that it is not true." 68

In keeping with his previously mentioned commitment to maintaining a civilized atmosphere at Vancouver, it is interesting to note that the doctor went as far as he could to ensure that every aspect of that cherished state be provided. This included seeing to the spiritual needs of employees at the fort. Before there was a clergyman assigned to the fort, it was McLoughlin's custom to conduct Sunday services himself in the large dining hall where he read from the ritual of the Church of England. If there was a clergyman present among the visitors he was invited to preach, regardless of his denomination. Years later after McLoughlin returned to the Catholic church Douglas conducted the services. A chapel was eventually constructed where weekday classes in the catechism were taught and Sunday prayers were read in French to other

\footnotetext{
${ }^{67}$ MacDonald, 198.

${ }^{68}$ Ibid., 233.
} 
individuals and families of that faith. ${ }^{69}$ It was the continued absence of a permanent chaplain, however, that prompted his request of company officials to send a clergyman who could deal exclusively with the religious needs of his people. Rich indicates that the unfortunate selection of Herbert Beaver was the personal choice of George Simpson. ${ }^{70}$

Not only was Beaver a poor selection to fulfill the needs of the Protestant employees, but it could not be assumed that the Church of England, which he represented, would meet the spiritual needs of the substantial number of French Canadians who were Roman Catholic. With this in mind the chief factor pressed also for the representation of Catholic priests. This request was refused initially by Simpson and the Committee, who were:

afraid that if the missions spread their labours outside the precincts of settlement they would become the focus for the growth of large and sedentary bands of Indians which would have both social and economic repercussions...they had quickly shown that the ornaments of

- the altar and the imposing ceremonies of the Catholic worship were indeed more suitable for captivating the attention of the natives than the cold and meaningless ceremony of the minister Waller, whose mission they derided as "Satan's Kingdom."17

Within a year, however, they thought better of their decision and allowed for passage of Fathers Demers and Blanchette to the Pacific Northwest, with orders to establish a mission in the Cowlitz valley. The arrival of the two "black robes" at Vancouver occurred in 1838 while McLoughlin was in London.

\footnotetext{
${ }^{69}$ Johnson, 115-116.

${ }^{70}$ Rich, Letters, First Series, cxvii.

${ }^{71}$ Rich, $\underline{\mathrm{HBC}}, 683$.
} 
In spite of his absence, they were received by James Douglas with dignity and respect.

After weighing the statistics of the four French Canadian families living in the Cowlitz against the twenty-eight living in the Willamette valley, Father Blanchette decided to remain with the latter, knowing that in so doing he was breaking the terms he had agreed upon with the Governor and Committee of the Hudson's Bay Company. In this decision he found no opposition from Chief Factor McLoughlin, who even at this stage of his career apparently esteemed the needs of individuals as more important than rigid company formality. Subsequently, the first Roman Catholic services were held in a log cabin at Champoeg on January $6,1839 .{ }^{72}$

McLoughlin's concern for the welfare of his employees was not merely limited to affairs of business, discipline and religion. When John Ball, a noted and gifted school teacher and lawyer from New England, arrived in the Wyeth party of 1832 , the doctor was quick to note a kindred spirit and the two struck up a friendship. Unwilling to continue to accept the hospitality of Fort Vancouver's chief factor without rendering some type of service in return, the visitor appealed to his host for an opportunity to be of service. His concern, as might be expected, was dismissed as being unimportant and unnecessary. However, the fair-minded New Englander insisted on rendering a service of some type and McLoughlin, sensing a way to meet multiple needs, finally

\footnotetext{
${ }^{72}$ Montgomery, 253.
} 
acquiesced and offered to find a suitable way to put his talents to work. Of the agreement, Ball had the following to say:

I, of course, gladly accepted the offer. So he [the doctor] sent the boys to my room to be instructed, all half-breed boys of course, for there was not then a white woman in Oregon....Well, I found the boys docile and attentive and making good progress, for they are precocious and generally better boys than men. And the old doctor used to come in and see the school and seemed much pleased and well satisfied. And one time he said, "Ball, anyway you will have the reputation of teaching the first Academy in Oregon."73

The school progressed well through the first winter, and by the following summer all of the twenty-four students were conversing in English, the language that none except the chief factor's son David, spoke previously. Grammar and arithmetic were also part of the curriculum. The doctor's classroom visits helped ensure that the venture would be successful. On one occasion, when a disagreement occurred between the school master and one of his pupils, McLoughlin happened to arrive on the scene in time to offer his own brand of discipline. Assessing the situation quickly, he yanked the offending youngster from his seat and, after a short but efficient interview, expanded his vision to better appreciate the instructor's point of view. The school flourished under the careful supervision of John Ball until March 1, 1833, when the pioneer teacher retired to the Willamette to try his luck at farming. The classes were then taken over by Solomon H. Smith, another man

${ }^{73}$ Autobiography of John Ball, ed., Kate Ball Powers, Flora Ball Hopkins and Lucy Ball, (Grand Rapids: 1925), copy located at Oregon Historical Society. 
who had come West with Wyeth. ${ }^{74}$

In a letter to his brother, Edward, we learn that the son of Francis Ermatinger was taken in by the McLoughlins and cared for while his father was away from the fort. As mentioned previously, trouble developed at the school eventually and the boy had been withdrawn. He was subsequently sent to spend some time with his uncle, in the hopes that he would learn a few more civilized attributes than those he had initially gained at Vancouver.

To give you a character of the Boy, I am unable. This much I think, that he is vicious and requires a curb. At Vancouver he remained too long; not that I have to complain of the kindness of Mr. McLoughlin's family, as far as giving him plenty to eat and, I believe, good will, but they have so many about them, of all tribes, that they cannot pay the attention to them that children require. The consequences are that their morals are not good, nor their habits of cleanliness charming....His ears, too, have been neglected. They are equal to those of my mule, and I doubt whether, even with care, they can be brought to a reasonable compass. $^{75}$

The majority of Company laborers in Oregon were French Canadians. His treatment of them was typical of all who worked under his management. To those whose service had been exemplary, he showed his appreciation. For Pierre Lacourse, whom he described as having a "most excellent character", he recommended that he should be allowed "every indulgence consistent with regulations of the Service. ${ }^{176}$ Similar arrangements were to be made for

${ }^{74}$ Read Bain, "Educational Plans and Efforts by Methodists in Oregon to 1860", Oregon Historical Society Quarterly, Vol. 21, 1920, 65.

${ }^{75}$ MacDonald, 198.

${ }^{76}$ Barker, Letters, 282. 
Augustine Roussil, a "worthy honest deserving man."77 When such valuable men considered leaving the region as their contracts expired, the chief factor thought it appropriate that "every endeavour consistent with the Regulations of the concern must be made to induce them to renew their Engagements." ${ }^{78}$ On the other hand, those who were considered troublesome were treated accordingly. Antoine Valle, was determined to have been favored unjustly and "ought not to have been allowed wages as we never allow any thing to freemen who return as supernumeraies." ${ }^{179}$ The doctor was quick to make an adjustment in the case of Joseph Lapierre, who mistakenly had been "allowed regular rations of Pork and flour which we even do not allow tradesmen at this place ... You will therefore discontinue this regular allowance and only issue it to him when you think his conduct deserves such indulgence." ${ }^{180}$

Those who retired after years of honorable service found Chief Factor McLoughlin willing to assist their transition into private life. In 1828, a retiring French Canadian named Louis Labonte had sought permission to start a small farm in the Willamette valley. Company policy, however, demanded that when an employee's term of service had expired, he was to be discharged from the place of his original enlistment. The policy had been interpreted by

\footnotetext{
${ }^{77}$ Barker, Letters, 279.

${ }^{78}$ Ibid., 193.

${ }^{79}$ Ibid., 282.

${ }^{80}$ Ibid., 87.
} 
Governor Simpson as a precaution to keep undesirable whites from being turned loose among the Indians, "where, if they were inclined, they could incite the Indians to rebellion." ${ }^{81}$ Though certainly believing that the man was no risk, the doctor, nevertheless was forced to refuse his request. Labonte, on the other hand, not to be undone by a mere matter of red tape, journeyed to Montreal, secured his discharge and returned to settle in the Willamette.

By 1829 when Etienne Lucier, the next retiring employee to seek discharge and settlement in the region, McLoughlin had devised a way to circumvent the regulation. "If he went to Canada and unfortunately died before his children could provide for themselves," he wrote, "they would become objects of pity and a burden to others--for these reasons I would assist him." 82 To avoid breaking the policy, the doctor decided to retain Lucier's name on the company roster and at the same time loaned him provisions enough to sustain a small family. The arrangement required that payment would be made from the produce of the farm. Other retiring servants were quick to see the benefits of such an arrangement and took advantage of it. Their settlement thrived and soon became known as "French Prairie." 83

After the first wagon trains began arriving from the states in 1842 these company settlers approached the doctor expressing fears that they would

${ }^{81}$ McLoughlin, "Autobiographical Sketch", Oregon Pioneer Association Proceedings.

${ }^{82}$ Ibid.,

${ }^{83}$ Montgomery, 158-159. 
eventually be absorbed into the United States. He told them that "the American Government and people know only two classes of persons," rogues and honest men; that they punish the first and protected the last, and it depended only upon themselves to what class they would belong." ${ }^{84}$ It is doubtful that McLoughlin was thinking about the inevitability of his own retirement at that juncture of his life, but his later determined stance regarding his property claims near the falls in Oregon City came soon enough to show that he was not slow to recognize the prospects of an eventual settlement south of the Columbia. The events that followed, however, did not make the transition pleasant or easy when it came.

The turning point in his life, and the beginning of his most serious difficulties with Simpson and the company, began in 1842 . The history of the two men finds them at odds on more than one occasion, however. The latter's insistance that every last bit of competition be eliminated was esteemed as "small- minded and needlessly costly," to the doctor, who cared little about "casual traders on the fringes." ${ }^{15}$ By 1841 , competition had largely been eliminated and Simpson moved to close the smaller posts down and suggested the relocation of the post on the Columbia to the southern tip of Vancouver Island in Puget Sound. This widened the breech that existed between the two men, as McLoughlin was loathe to relinquish the flourishing fruits of his

\footnotetext{
${ }^{84}$ McLoughlin, "Sketch".

${ }^{85}$ Williams, "Fur Trade", 65.
} 
labors, which by then included farms, orchards, livestock, a salmon industry and a sawmill, ${ }^{86}$ besides his property interests on the Willamette. Nothing, however, had a more damaging impact on the relations between McLoughlin and his superiors than the circumstances surrounding the murder of his son, John Jr.

The doctor had hoped that John would follow his footsteps into the medical profession but such hopes did not come to fruition. Instead, through his father's instrumentality, a place was found for him in the fur trade. Hoping to provide an opportunity for him to succeed, the elder McLoughlin assented to his son's assignment in 1840 to Fort Stikine, recently acquired from the Russian American Company and located at the mouth of the Stikine river, facing Sitka Island. At the age of thirty and already possessed with a reputation for being headstrong, the young McLoughlin left for his assignement accompanied by Roderick Finlayson and twenty HBC laborers. Soon, however, Finlayson was transferred to Fort Simpson and the young McLoughlin was in sole command of the men and the fort. From the outset things did not go well. Relations with the local Indians were tense and security measures had to be tight. The fort was in dire need of repair and in the following letter to John Work, his immediate superior, it is apparent that the young McLoughlin was concerned about other problems that were possibly more serious:

${ }^{86}$ Williams, "Fur Trade", 66. 
I think it my duty to inform you that I shall have a great many alterations to make in this Fort in course of next summer, and if no exchange of men takes place, I shall not be able to do more than half of the work, if it is in your power to remove some of the useless hands I should be very thankful, we require men that can do their duty but the most part of the men here are not able to make themselves useful in any way. I think the demand I now ask is perfectly necessary in order to enable me to surround our Fort with new Piquets next summer. ${ }^{87}$

This is the first indication that personnel problems were brewing. The fact that nothing was done promptly to alleviate the situation allowed tensions to escalate. The result was a mutiny which culminated in the brutal murder of the young McLoughlin. This alone would have been sufficient to break the heart of a loving parent, but the handling of the investigation that followed was more than the senior McLoughlin could countenance. The report of George Simpson, who managed the investigation, was incomplete and unjustifiable. London initially treated the murder with the greatest caution. In their December 21, 1842 dispatch to McLoughlin they made no reference to the incident even though it was written after Simpson had arrived in London and had made his report. As additional evidence gathered by McLoughlin began to arrive the following year, the confidential opinions of members of the Committee began to swing away from Simpson's interpretation of the tragedy ${ }^{88}$ Assumption that the younger McLoughlin's mishandling of affairs at the fort because he was a drunkard and treated his men cruelly became

\footnotetext{
${ }^{87}$ Rich, Letters, Second Series, xxxv.

${ }^{88}$ Ibid., xxxv.
} 
doubtful when an examination of the records revealed that little of his liquor supply had been used, and his harshness consisted of "confining the men to their barracks at night and not allowing them to receive Indian women, and that the murder had been premeditated." ${ }^{189}$ Archibald Barclay, Secretary to the Governor and Committee, wrote privately to Simpson the following letter in June, 1843:

I need not say any thing about the new light thrown on the murder of Young McLoughlin at Stikine since you were there, as you will have seen the depositions taken in the case. The crime was clearly long premeditated and if ever men deserved hanging, Urbain Heroux, Pierre Kanaquasse and the scoundrel McPherson, ought to be strung up. It is evident that the charges of habitual intoxication and excessive severity were trumped up after the deed was committed as a screen to the villainy of the culprits The depositions are to be sent to the Govr. of Sitka and the sanction of our Governt. obtained for his dealing with them according to the Russian law...90

As the evidence was examined more carefully the Committee was increasingly convinced that Governor Simpson's position had been ill-taken, but so determined was his stand, that for them to publicly acknowledge his folly would mean disgrace for him and for them. This, the Committee was not willing to do and the grieving doctor was left to wage a battle for justice against odds even he could not defeat. His attempts to win justice became an obsession from which he could not rest. It dominated his thoughts to the point that he eventually held Governor Simpson personally responsible for the

\footnotetext{
${ }^{89}$ Sampson, xxxvi.
}

${ }^{90}$ Ibid. (Barclay to Simpson, June, 1843). 
tragedy. His public attacks became an embarrassment to the company. In a dispatch to the doctor from the Governor and Committee explaining their final position, they stressed only two points; the impossibility of bringing criminal charges against all the men at Stikine, and McLoughlin's personal attacks on Simpson. In defense of Simpson, Barclay asserted that the governor had been deceived by the characters of the men. He also pointed out that the doctor himself, had ample opportunity to protest the assignment of personnel at the fort. The fact that no such protest was made made it clear that McLoughlin "entertained no apprehension" for his son's safety. "You have thus virtually refuted your own charge," he went on to say, "and acquitted Sir George Simpson of any blame that does not equally attach to yourself." ${ }^{11}$ Rich assessed the situation in the following manner:

It is tempting, though futile, to speculate upon what might have happened if McLoughlin had acted somewhat differently. For the sorrow and humiliation the murder cost him one can have nothing but sympathy. Nor is it difficult to make allowance for his anger. Barclay and others in positions of importance so nearly agreed with him that they must have had very considerable respect for his point of view. If McLoughlin had only retained a better sense of proportion, and had not stressed so persistently the personal issue with Simpson, they might well have found means to give that respect practical expression. ${ }^{92}$

In regards to Sir George Simpson's role in the matter, Rich affirmed that the governor was:

\footnotetext{
${ }^{91}$ Rich, Letters, Second Series, 312.

${ }^{92}$ Ibid., xliii.
} 
Certainly wrong in his policy following the murder of McLoughlin's son. His action was arbitrary and callous, and constitutes one of the most serious blots on his career. Fortunately for him McLoughlin lost all sense of proportion in the matter, and circumstances gave the Governor and Committee no alternative but to support Simpson, at least in public. $^{93}$

By the spring of 1844, John McLoughlin had become such an embarrassment to the Hudson's Bay Company that the Committee began making plans to remove him from further service. The other factors regarding his policy with the American settlers only rendered their decision easier. In February of 1846 , the doctor finally acknowledged his defeat in a letter to his friend Edward Ermatinger: " ...as my only object in prosecuting was to ascertain the truth in a fair Examination of witnesses and as it would cost to send the case to England where alone it can be tried at Least ten thousand pounds which is more than I can spare I must drop proceedings..." 94

In his last correspondence to the Committee as a servant, written on July 12, 1846, the "Great White Eagle" crossed another Rubicon, from which there was no turning back. In it, as he tendered his resignation, his bitterness and sense of injustice are painfully apparent. He expressed a desire to go to London and Red River to receive an explanation for "the Injury and wrongs done" to his character and fortune. Though his future as a private citizen held no great promise of success at this stage of his life, he nevertheless was moved

\footnotetext{
${ }^{93}$ Rich, Letters, Second Series, xlix.

${ }^{94}$ Ibid., xlviii.
} 
to state that he would "not Return to active Duty in the service of the Hudson's Bay Company." 95

There is no indication from the record that when John McLoughlin passed through the gates of Fort Vancouver for the last time, he ever looked back with regret. He had served his time as ruler on the banks of the Columbia and now it was left in the capable hands of his long-time friend and associate, James Douglas. A similar seat did not await him along the banks of the Willamette in Oregon City. Indeed, he left one bitter fight only to re-engage in another, and for the "Good Doctor", it would have a similar bitter end.

${ }^{95}$ Rich, Letters, Third Series, 170. 


\section{CONCLUSION}

There are many ways to judge the make of a man. Among the most revealing are those which indicate how well he represents himself when placed in various circumstances and situations. For instance, how does he react when in the role of a subordinate and does it change when he is among his peers, or placed in a position of leadership? Does his disposition change measurably when dealing with those whose differences are in the realm of race, religion, educational training, culture or economic standing? Equally revealing, is how well he holds up under fire, regardless of whose company he is in.

"Circumstance does not make the man," writes James Allen, "it reveals him to himself." C.S. Lewis explained that how a man responds to a situation which comes upon him suddenly is the best evidence for what sort of man he is. "If there are rats in the cellar," he reasons, "you are most likely to see them if you go in very suddenly. But the suddenness does not create the rats: it only prevents them from hiding. In the same way the suddenness of the provocation does not make me an ill-tempered man: it only reveals to me what an ill-tempered man I am."

As has been illustrated, John McLoughlin possessed a temper that could quickly reach the boiling point and spill over to scald anyone who happened

${ }^{1}$ James Allen, As a Man Thinketh, (New York: Grosset \& Dunlap: The Family Inspirational Librarys, 1973), 16. $164-165$.

${ }^{2}$ C.S. Lewis, Mere Christianity, (New York: The Macmillan Company, 1958), 
to have the misfortune of being the focus of his indignation. It was that very quality which proved, in the end, to be his undoing. On the other hand, he could exhibit a generous and kindly nature, through which he could exercise great benevolence and forbearance. It was that quality which won him a place in the hearts of many, who came to know him in his wilderness outpost, whether a down-on-his-luck trader accepting his hospitality at the fort, or a destitute immigrant whose chances of survival in an unmerciful wilderness were slim if not for the timely assistance he rendered.

Among the greatest controversies surrounding John McLoughlin is his decision to assist the American settlers against the wishes of his employers. To fully consider this issue one would have to weigh the available facts in order to surmize and appreciate what likely would have occurred had he not done so. After having observed the force of United States westward expansion is it realistic to imagine that the American settlers could have been kept from the Columbia region had the doctor followed a policy more consistent with the wishes of the Governor and Committee of the Hudson's Bay Company? Or in considering the recent history of conflict between Britain and the United States, is it likely that such a posture would have brought the two nations into another war which neither could have afforded but which circumstances would have demanded? Surely such issues would be considered differently depending somewhat on which country the researcher represented. For the British, the failures of John McLoughlin constituted a major setback in their 
ability to hold on to a remote corner of their shrinking empire. For the Americans, his benevolence paved the way for a peaceful settlement and the eventual acquisition of a rich corner of their expanding national domain. From either point of view his impact on the history of two nations is substantial.

His career, thus, is one that marks the passing of the baton of influence from a weakening Old World power of the past to a growing New World power of the future. In this, John McLoughlin stood at the crossroads of history and as such, his value in that history should be measured, not by the prejudice of whose flag he stood under, but by the overall contribution his effort made to the thrust of civilization. This we can do only if, indeed, we can agree that what we term as "civilization", stands more for the promotion and welfare of the quality of human life than for the interests of a particular nation.

Lowoenberg contends that no one had more of an impact on the early history of Oregon and the Pacific Northwest than Sir George Simpson. He notes his history as governor of all four departments of the company in British North America from 1826 to 1860 and his elevation to knighthood in 1842 in recognition of his efforts. ${ }^{3}$ Laut, on the other hand argues that "though Oregon is under Governor Simpson's direction, it becomes a kingdom by itself, with McLoughlin the sole autocrat." ${ }^{4}$ Certainly Lowoenberg is correct if the history

\footnotetext{
${ }^{3}$ Loewenberg, 19.
}

${ }^{4}$ Agnes C. Laut, The Conquest of the Great Northwest, (New York: Moffat, Yard and Company, 1908), 305. 
of the Columbia is measured only in terms of Hudson's Bay Company policies and who was behind their formulation. It could also be argued that such individuals as John McLoughlin, Hall J. Kelly, or Thomas H. Benton, each in their own unique way contributed equally to that same history. Their collective regard for $\mathrm{HBC}$ policy ranged from obedient compliance with the wink of an eye to outright contempt.

While the purpose of this work is not to identify John McLoughlin as the key figure in 19th Century Northwest history, it is its intent to focus on the contribution he did make, the tools he did it with and the unique set of circumstances he was forced to labor under. Relatively Few people have found themselves in similar positions of leadership as that of Dr. McLoughlin. In the course of his responsibilities, he was asked to successfully manage the commerce of a vast and sprawling branch of an international business which owed much of its success to its ability to operate as a revenue-generating, privately owned enterprise which possessed the force and precision of a trained arm of the military. He was asked to serve as judge, counselor, and negotiator in the affairs of all those who interacted with the company whether as employee, trapper, Indian, missionary or competitor. This, he did while maintaining a record clear of scandal or any substantiated accusation of selfpromotion or abuse of power. This, he did while creating and sustaining a remote, yet bustling center of civilization, amidst a raw and hostile wilderness, where two diametrically opposed cultures could interact to their mutual 
advantage. This, he did while overseeing the welfare of personnel as ethnically diverse as any ever assembled for a similar purpose. This, he did in a political atmosphere between two nations whose recent belligerence and current ambitions did little to allay tensions between them.

Such were the seas the doctor was forced to swim in, and whose currents would've swept a lesser man away. The controversy which still surrounds him is best understood in light of how one perceives his successes and failures. The first jobs of management, according to Peter F. Drucker, is the successful management of the business, followed by the management of the managers and lastly, the management of the workers and the work. ${ }^{5}$ In this, the doctor succeeded. Where he failed, in the eyes of the Hudson's Bay Company, was in the fact that he eventually placed his personal goals and those of an alien population above his expected loyalty to the goals of the organization. Whereas the stated goal of most business ventures is to maximize profits, according to John Ladd, "their actual, operative goals are the securing of their survival, autonomy and economic growth." ${ }^{\prime 6}$ It is the natural responsibility of an officer within an organization to adopt a course of service that will promote such goals. Thus, according to the impersonal code of business, an individual

${ }^{5}$ Peter J. Drucker, The Practice of Management, A Study of the Most Important Function of American Society, (New York: Amacom; Albuquerque: Newman Communications Corp., 1977), 6.

${ }^{6}$ John Ladd, Morality and the Ideal of Rationality in Formal Organizations, article in Thomas Donaldson and Patricia H. Werhane, Philosophical Issues in Business Ethics, ( Englwood Cliffs: Prentis Hall, Inc., 1979),103. 
violates basic rules of management when he allows his moral scruples, rather than the objectives of the organization, to govern his decision making.

In placing his own interests, as in the case of his obsession with holding George Simpson responsible for the murder of his son, and in placing his moral interests, as in the case of his generous assistance to the American immigrants, above the interests of the HBC, John McLoughlin clearly became a hindrance. For the Governor and Committee, as we have seen, there was only one course of action for them to pursue. "If an individual official makes a mistake or does something that fails to satisfy this criterion of social decision," states Ladd, "he will be said to have 'exceeded his authority,' and will probably be sacked or made vice-president!"7 The decision of John McLoughlin to tender his resignation in 1846 was probably met in London with a great sigh of relief. It may well have had a similar effect on the doctor, himself. If he left the service of the company with such sentiments, however, his respite from turmoil was to be short-lived.

Another criteria for the measure of a man is his determination to set for himself, and maintain a set of standards by which he governs his life, and from which he will not vary, regardless of the odds against him. In pursuing justice for the brutal murder of his own son, he sought the upholding of a law that neither his superior, nor his employers were willing to administer. In filling the outstretched hand of the naked and fainting immigrant, he appealed

\footnotetext{
${ }^{7}$ Donaldson, 103.
} 
to a law higher than that enacted by men and nations. If in doing either, he incurred the indignity of his company and country, he understood the price and did not shrink from its payment. Whether the doctor ever read Benjamin Franklin's sentiments regarding such things is unknown, but in them he would have found reasoning with which to agree:

We stand at the crossroads each minute, each hour, each day, making choices. We choose the thoughts we allow ourselves to think, the passions we allow ourselves to feel, and the actions we allow ourselves to perform. Each choice is made in the context of whatever value system we've selected to govern our lives. In selecting that value system, we are, in a very real way, making the most important choice we will ever make.

Those who believe there is one God who made all things and who governs the world by his Providence will make many choices different from those who do not. Those who hold in reverence that being who gave them life and worship Him through adoration, prayer, and thanksgiving, will make choices different from those who do not. Those who believe in a future state in which all that is wrong here will be made right, will make many choices different from those who do not. Those who subscribe to the morals of Jesus will make many choices different from those who do not.

Since the foundation of all happiness is thinking rightly, and since correct action is dependent on correct opinion, we cannot be too careful in choosing the value system we allow to govern our thoughts and actions. And to know that God governs in the affairs of men, that he hears and answers prayers, and that he is a rewarder of them that diligently seek Him, is indeed, a powerful regulator of human conduct. ${ }^{8}$

The remaining years of the doctor's life speak for his continued adherence to his convictions. Historians, governments and organizations may judge him

${ }^{8}$ George L. Rogers, Ben Franklin's, The Art of Virtue: His Formula for Successful Living, (Eden Prairie: Acorn Publications, 1986), 88-90. 
as they choose, but his own concerns for where he would turn to receive the judgement he valued are found in his last words: "A Dieu."

${ }^{9}$ De Chesne, Henri, "Letter to Eva Emery Dye, 1893", Oregon Historical Society, \# 1089. 


\section{BIBLIOGRAPHY}

\section{PRIMARY SOURCES}

Barker, Burt Brown. ed. Letters of Dr. John McLouhlin, Written at Fort Vancouver, 1829-1232. Portland: Binfords \& Mort, for the Oregon Historical Society, 1948.

. The McLoughlin Empire and its Rulers, Family Letters of the McLoughlins. Glendale: A. H. Clark Company, 1959.

Barry, J. Neilson. "Columbia River Exploration, 1782". Oregon Historical Society Quarterly. Vol. 27, 1926.

Beals, Herbert K. ed. For Honor \& Country, the Diary of Bruno de Hezeta . Portland: Western Imprints, The Press of the Oregon State Historical Society. 1985.

Cosgrove, Hugh. "Reminiscences of Hugh Cosgrove". Oregon Historical Society Quarterly. Vol. 1, 1900.

De Chesne, Henri. "Letter to Eva Emery Dye, 1893". Oregon Historical Society. \# 1089

Ermatinger, Francis. "Earliest Expeditions Against Puget Sound Indians". Washington Historical Society Quarterly. Vol. 1, 1907.

Gay, Theresa. ed. Life and Letters of Mrs. Jason Lee. Portland: Metropolitan Press, 1936.

Harriot, J. E. "Correspondence". Oregon Historical Society Quarterly. Vol. 2, 1901.

Hill, Sarah. "Letters of Sarah Hill". Oregon Historical Society. \#1508.

Hines, Gustavus. Missionary Expedition to Oregon. New York: Arno Press, $1973, \mathrm{c} 1850$.

Hines, H. K. Missionary History of the Pacific Northwest. Chicago: The Lewis Publishing Company, 1893.

Lee, Jason. "Journal". Oregon Historical Society Quarterly. Vol. 17, 1916. 
MacDonald, Lois Halliday, ed. The Fur Trade Letters of Francis Ermatinger. Glendale: A. H. Clark Company. 1980.

McLoughlin, Dr. John. "Autobiographical Sketch". Oregon Pioneer Association Proceedings.

McLoughlin, John. "A Narrative by Dr. McLoughlin". Oregon HIstorical Society Quarterly. Vol. 1, 1900.

Merk, Frederick. ed. George Simpson's Journal; Fur Trade and Empire. XXXI. Cambridge: Harvard University Press. 1931.

Powell, Fred Wilbur. ed. Hall I. Kelley on Oregon. Princeton: Princeton University Press. 1932.

Powers, Kate Ball; Hopkins, Flora Ball and Lucy Ball. ed. Autobiography of John Ball. Grand Rapids: 1925.

Quaife, Milo Milton. Gabriele Franchere, A Voyage to the Northwest Coast of America . New York: The Citadel Press. 1968.

Sampson, William R. ed. John McLoughlin's Business Correspondence, 1847-48. Published in cooperation with the Washington State Historical Society. Seattle and London: University of Washington Press.1973.

Slacum, William A. Oregon Historical Society Quarterly. Vol. 8, 1907.

Waiter, W. W. "Reminiscences of a 45'er". Oregon Historical Society. \# 739.

Wilkes, Charles. "Diary of Wilkes in the Northwest," Washington Historical Society Quarterly. Vol. 16.

Whitman, Narcissa. "Letters, 1836-1839". Oregon Historical Society. \# 1508.

Young, Frederick G. ed. Sources of the History of Oregon, Correspondences and Journals of Nathaniel Jarvis Wyeth. Vol. I, Eugene: University Press. 1899. 


\section{GENERAL WORKS}

Allen, James. As A Man Thinketh. New York: Grosset \& Dunlap. Family Inspiriational Library. 1973.

Bancroft, Hubert Howe. History of the Northwest Coast, 2 Vols. New York. The Bancroft Company. 1884.

Clarke, S. A. Pioneer Days in Early Oregon, 2 Vols. Portland: J. K. Gill Company. 1905.

Donaldson, Thomas and Patricia H. Werhane. Philosophical Issues in Business Ethics. Englewood Cliffs: Prentis Hall, Incorporated. 1979.

Drucker, Peter J. The Practice of Management, A Study of the Most Important Function of American Society. New York: Amacom; Albuquerque: Newman Communications Corporation. 1977.

Fogdall, Alberta Brooks. Royal Family of the Columbia: Dr. John McLoughlin and His Family. Portland: Binfords \& Mort, Publishers. Second (Bicentennial) edition. 1982.

Holman, Frederick V. Dr. John McLoughlin. Cleveland: The A. H. Clark Company. 1907.

Hussey, John A. History of Fort Vancouver. Tacoma: Washington State Historical Society. 1957.

Jeffrey, Julie Roy. Converting the West, A Biography of Narcissa Whitman. Norman: Univeristy of Oklahoma Press. 1991.

Johnson, Robert C. John McLoughlin, Father of Oregon. Portland: Binfords \& Mort. 1958, c1935.

Laut, Agnes C. The Conquest of the Great Northwest. New York: Moffat, Yard \& Company. 1908.

Lewis, C. S. Mere Christianity. New York: The Macmillan Company. 1958.

Loewenberg, Robert J. Equality on the Oregon Frontier, Jason Lee and the Methodist Mission. Seattle and London: University of Washington Press. 1976. 
Merk, Frederick. The Oregon Question, Essays in Anglo-American Diplomacy and Politics. Cambridge: The Belknap Press of Harvard University Press. 1967.

Montgomery, Richard G. The White Headed Eagle, John McLoughlin, Builder of an Empire. Norwood: The Macmillan Company. 1934.

Rich, Edwin Ernest. History of the Hudson's Bay Company, 1670-1870. Hudson's Bay Record Society series. London: Hudson's Bay Record Society. 1958-59.

- McLoughlin's Fort Vancouver Letters. First Series 1826-1839. Second Series 1839-1844; Third Series 1844-1846. London: Hudson's Bay Record Society. 1943, 1944.

Rogers, George L. Ben Franklin's, The Art of Virtue; His Formula for Successful Living. Eden Prairie: Acorn Publications. 1986.

Ruby, Robert $\mathrm{H}$. and John A. Brown. The Chinook Indians, Traders of the Lower Columbia. Norman: University of Oklahoma Press. 1965.

\section{ARTICLES, PERIODICALS, QUARTERLIES}

Douthit, Nathan. "Hudson's Bay Company Relations with Southwest Oregon Indians". Oregon Historical Society Quarterly. Vol. 93. Spring 1992.

Elliott, T. C. "John McLoughlin and his Guests". Washington Historical Society Quarterly. Vol. III, No. 1. October 1908.

. "Margaret Wadin McKay McLoughlin". Oregon Historical Society Quarterly. Vol. 36. December 1935.

Hussey, John A. "'Unpretending' But Not 'Indecent': Living Quarters at Mid19th Century Hudson's Bay Company Posts". The Beaver. Summer 1975.

. "The Women of Fort Vancouver". Oregon Historical Society Quarterly. Vol. 92, No. 3. Fall 1991.

Morrison, Dorothy and Jean. "John McLoughlin: Relunctant Fur Trader".

Oregon Historical Society Quarterly. Vol. LXXXI. No. 4. Winter 1980. 
Nokes, Richard J. Columbia's River, The Voyages of Robert Gray, 1787-1793. Washington State Historical Society: Published in conjunction with the 1992 International Maritime Bicentennial.

Reid, John Phillip. "Restraints of Vengeance: Retaliation-in-kind, Use of Indian Law in the Old Oregon Country". Oregon Historical Society Quarterly. Vol. 95. No. 1. Spring 1994.

"Settlement On the Oregon River". 20 Congress, I Session. H. doc. 139.

Williams, Glyndwr. "Governor George Simpson's Character Book". The Beaver. Summer, 1975.

. "The Hudson's Bay Company and the Fur Trade, 1670-1870". The Beaver. Autumn 1983. 